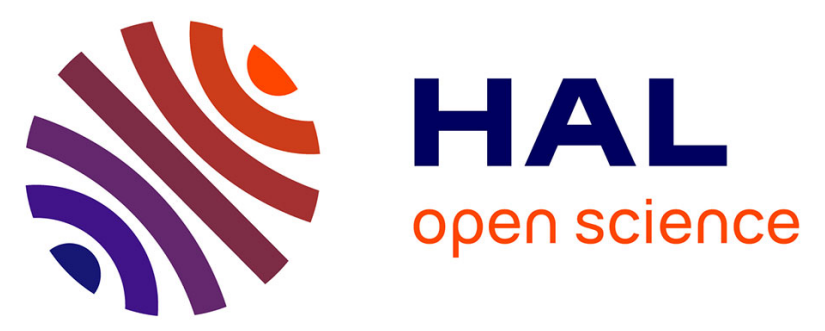

\title{
Hydrothermal system of Central Tenerife Volcanic Complex, Canary Islands (Spain), inferred from self-potential measurements
}

Víctor Villasante-Marcos, Anthony Finizola, Rafael Abella, Stéphanie Barde-Cabusson, María José Blanco, Beatriz Brenes, Víctor Cabrera, Benito Casas, Pablo de Agustín, Fabio Di Gangi, et al.

\section{To cite this version:}

Víctor Villasante-Marcos, Anthony Finizola, Rafael Abella, Stéphanie Barde-Cabusson, María José Blanco, et al.. Hydrothermal system of Central Tenerife Volcanic Complex, Canary Islands (Spain), inferred from self-potential measurements. Journal of Volcanology and Geothermal Research, 2014, 272, pp.59-77. 10.1016/j.jvolgeores.2013.12.007 . hal-01147430

\section{HAL Id: hal-01147430 \\ https://hal.science/hal-01147430}

Submitted on 19 May 2017

HAL is a multi-disciplinary open access archive for the deposit and dissemination of scientific research documents, whether they are published or not. The documents may come from teaching and research institutions in France or abroad, or from public or private research centers.
L'archive ouverte pluridisciplinaire HAL, est destinée au dépôt et à la diffusion de documents scientifiques de niveau recherche, publiés ou non, émanant des établissements d'enseignement et de recherche français ou étrangers, des laboratoires publics ou privés. 


\title{
Hydrothermal system of Central Tenerife Volcanic Complex, Canary Islands (Spain), inferred from self- potential measurements
}

\author{
Víctor Villasante-Marcos $^{\mathrm{a}, *}$, Anthony Finizola ${ }^{\mathrm{b}}$, Rafael Abella a , Stéphanie Barde-Cabusson ${ }^{\mathrm{c}}$, \\ María José Blanco ${ }^{\mathrm{d}}$, Beatriz Brenes ${ }^{\mathrm{a}}$, Víctor Cabrera ${ }^{\mathrm{d}}$, Benito Casas ${ }^{\mathrm{d}}$, Pablo De Agustín ${ }^{\mathrm{a}}$, Fabio Di Gangi \\ e \\ Itahiza Domínguez ${ }^{\mathrm{d}}$, Olaya García ${ }^{\mathrm{d}}$, Almudena Gomis a , Juan Guzmán ${ }^{\mathrm{d}}$, Ilazkiñe Iribarren ${ }^{\mathrm{d}}$, \\ Guillaume Levieux ${ }^{\mathrm{f}}$, Carmen López ${ }^{\mathrm{a}}$, Natividad Luengo-Oroz ${ }^{\mathrm{a}}$, Isidoro Martín ${ }^{\mathrm{d}}$, Manuel Moreno ${ }^{\mathrm{d}}$, \\ Stavros Meletlidis $^{\mathrm{d}}$, Julie Morin ${ }^{\mathrm{b}}$, David Moure ${ }^{\mathrm{d}}$, Jorge Pereda ${ }^{\mathrm{d}}$, Tullio Ricci ${ }^{\mathrm{g}}$, Enrique Romero ${ }^{\mathrm{d}}$, \\ Claudia Schütze ${ }^{\mathrm{h}}$, Barbara Suski-Ricci ${ }^{\mathrm{i}}$, Pedro Torres ${ }^{\mathrm{d}}$, Patricia Trigo ${ }^{\mathrm{a}}$ \\ a Observatorio Geofísico Central, Instituto Geográfico Nacional, C/Alfonso XII, 3, 28014 Madrid, Spain

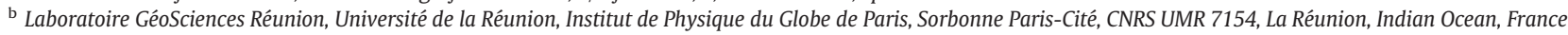 \\ c Institute of Earth Sciences Jaume Almera, ICTJA-CSIC, Lluis Sole I Sabaris s/n, Barcelona, Spain

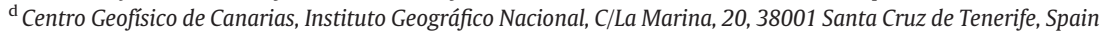 \\ e Istituto Nazionale di Geofisica e Vulcanologia, Palermo, Italy \\ ${ }^{\mathrm{f}}$ Institut de Physique du Globe de Paris et Université Paris Diderot, Sorbonne Paris-Cité, CNRS UMR 7154, Paris, France \\ ${ }^{\mathrm{g}}$ Istituto Nazionale di Geofisica e Vulcanologia, Roma, Italy \\ ${ }^{\mathrm{h}}$ UFZ-Helmholtz Centre for Environmental Research, Leipzig, Germany \\ ${ }^{\text {i } M E M S F I E L D, ~ M E M S ~ a n d ~ N a n o-T e c h n o l o g i e s ~ C o n s u l t a n c y, ~ C l a m a r t, ~ F r a n c e ~}$
}

A B S T R A C T

An extensive self-potential survey was carried out in the central volcanic complex of Tenerife Island (Canary Islands, Spain). A total amount of $\sim 237 \mathrm{~km}$ of profiles with $20 \mathrm{~m}$ spacing between measurements was completed, including radial profiles extending from the summits of Teide and Pico Viejo, and circular profiles inside and around Las Cañadas caldera and the northern slopes of Teide and Pico Viejo. One of the main results of this map-ping is the detection of well-developed hydrothermal systems within the edifices of Teide and Pico Viejo, and also associated with the flank satellite M. Blanca and M. Rajada volcanoes. A strong structural control of the surface manifestation of these hydrothermal systems is deduced from the data, pointing to the subdivision of Teide and Pico Viejo hydrothermal systems in three zones: summit crater, upper and lower hydrothermal systems. Self-potential maxima related to hydrothermal activity are absent from the proximal parts of the NE and NW rift zones as well as from at least two of the mafic historical eruptions (Chinyero and Siete Fuentes), indicating that long-lived hydrothermal systems have developed exclusively over relatively shallow felsic magma reser-voirs. Towards Las Cañadas caldera floor and walls, the influence of the central hydrothermal systems disappears and the self-potential signal is controlled by the topography, the distance to the water table of Las Cañadas aqui-fer and its geometry. Nevertheless, fossil or remanent hydrothermal activity at some points along the Caldera wall, especially around the Roques de García area, is also suggested by the data. Self-potential data indicate the existence of independent groundwater systems in the three calderas of Ucanca, Guajara and Diego Hernández, with a funnel shaped negative anomaly in the Diego Hernández caldera floor related to the subsurface topogra-phy of the caldera bottom. Two other important self-potential features are detected: positive values towards the northwestern Santiago rift, possibly due to the relatively high altitude of the water-table in this area; and a linear set of minima to the west of Pico Viejo, aligned with the northwestern rift and related to meteoric water infiltra-tion along its fracture system.

\section{Introduction}

Persistent active subaerial volcanism is usually accompanied by hydrothermal activity, which develops an energy transfer between the

\footnotetext{
* Corresponding author. Tel.: + $34915270107+0363$; fax: + 34915271935.

E-mail address: vvillasante@fomento.es (V. Villasante-Marcos).
}

deep magmatic reservoirs and the surface layers of a volcanic system. The heat exchange between these two distinct parts of a volcanic system is performed mainly by convection of subsurface fluids, both by groundwater circulation supplied by meteoric water recharge and also by the ascension of hot volcanic gasses liberated from deep magma cooling and gas exsolution during magma migration toward the surface (Giggenbach, 1996; Ingebritsen et al., 2006, 2010; Pirajno, 2009). 
Hydrothermal activity greatly enhances alteration and argillization of volcanic rocks and therefore constitutes one of the major agents in mechanical alteration of volcanic edifices (Siebert et al., 1987; Lopez and Williams, 1993; Wyk et al., 1997; Kerle et al., 2001; Reid et al., 2001; Wyk et al., 2001; Cecchi et al., 2005). Because of this, hydrothermal alteration is considered a major factor affecting volcano flank stability (Aizawa, 2008; Aizawa et al., 2009) and it is usually invoked to explain volcanic landslides and gravitational flank collapses, which are widely observed in volcanic oceanic islands (Le Friant et al., 2003, 2004; Merle and Lénat, 2003; Merle et al., 2006; Barde-Cabusson and Merle, 2007; Romagnoli et al., 2009a, 2009b). Hydrothermal systems can develop a strong coupling with the eruptive activity of their parent magmatic systems and sometimes the state of the hydrothermal system, its spatial dimensions and the intensity of the heat transfer can be used as a volcano monitoring tool (Aubert et al., 2008; Gaudin et al., 2013). The lateral extension and the geometry of a hydrothermal system are highly variable, depending on diverse factors, both internal to the volcanic system, like structural boundaries (caldera, craters, regional faults, weakness areas) and also external, like the pattern and magnitude of meteoric groundwater recharge by rain and snow (Finizola et al., 2004; Tort and Finizola, 2005; Barde-Cabusson et al., 2012; Peltier et al., 2012).

In the present work we have focused on the central area of Tenerife Island (Canary Islands, Spain), dominated by Teide and Pico Viejo stratovolcanoes and Las Cañadas caldera, in which active hydrothermal activity is evidenced by fumaroles, thermal anomalies and $\mathrm{CO}_{2}$ diffuse emission in Teide summit and upper-cone flanks. Several geophysical studies (gravimetric, magnetic, seismic and magnetotelluric) have been devoted to this area (Ablay and Keary, 2000; Araña et al., 2000; Canales et al., 2000; Pous et al., 2002; Coppo et al., 2008, 2009, 2010; Gottsmann et al., 2008; Blanco-Montenegro et al., 2011; Camacho et al., 2011) but only a few have focused on its hydrothermal system (García de la Noceda et al., 1989; Aubert and Kieffer, 1996; Ohno et al., 2004). The surface expression of Teide summit hydrothermal system has been recently studied by Del Potro et al. (2009), who analyzed also the mechanical properties of the clay-rich materials resulting from the hydrothermal alteration (alunite and kaolinite, Del Potro and Hürlimann, 2009). Although these two works provide a useful general cartography of upper-Teide hydrothermal field, no information is available about the subsurface extension and magnitude of the corresponding hydrothermal system.

Knowledge about Teide-Pico Viejo hydrothermal system can be very useful at least in two different ways. Firstly, any realistic investigation on the mechanical properties and inner strength of Teide-Pico Viejo edifices must take into account the extension, geometry and degree of hydrothermal alteration experienced by their subsurface materials, with obvious implications about the potential for future lateral collapses and about the possibility of any deformation having affected these volcanic edifices (for example volcano spreading, see Márquez et al., 2008). Secondly, it can serve to further develop volcano monitoring tools based on the observation of the state and intensity of the hydrothermal system associated to this volcanic area, either by periodic repetition of geophysical measurements in selected areas or by the installation of continuous monitoring.

The objective of our work has been to study (1) the extension, geometry and structure of the hydrothermal systems and (2) some hydrogeological main features of the Teide-Pico Viejo complex of Tenerife summit. We have chosen the self-potential method due to its sensitivity to subsurface fluid movement, which makes it an ideal tool to investigate hydrothermal activity and its interaction with structural boundaries in volcanic edifices (Corwin and Hoover, 1979; Revil and Pezard, 1998; Revil et al., 1999a,b, 2004, 2008; Finizola et al., 2002, 2003, 2004, 2006; Zlotnicki and Nishida, 2003; Ishido, 2004). Our results will be compared with other complementary geophysical studies already performed in the summit part of Tenerife Island.

\section{Geological setting}

The bulk of Tenerife Island consists of basaltic materials accumulated over the seafloor since at least the middle Miocene, forming a basaltic shield whose oldest subaerial exposures are probably older than 11.9 Ma (Abdel-Monem and Watkins, 1972; Ancochea et al., 1990; Thirwall et al., 2000; Guillou et al., 2004). The eroded remnants of this shield-building phase make up the Anaga, Teno and Roque del Conde massifs (see Fig. 1). Later, the emission of more evolved magmas (mainly basalts, trachytes and phonolites) constructed the Las Cañadas edifice in the centre of the island, which has experienced several constructive-destructive cycles between $<4$ Ma and $\sim 0.17$ Ma ago (Ancochea et al., 1990; Martí et al., 1994; Bryan et al., 1998; Ancochea et al., 1999; Martí and Gudmundsson, 2000; Edgar et al., 2007). This central activity has been coetaneous with basaltic emissions along two clear rift systems (the Dorsal and Santiago rift systems, the "NE rift zone" and the "NW rift zone" respectively in Fig. 1) and in a more diffuse southern basaltic field called "S volcanic zone" in Fig. 1 (Ancochea et al., 1990; Carracedo et al., 2007).

The constructive-destructive cycles affecting Las Cañadas edifice are responsible for the formation of Las Cañadas caldera, a NE-SW elliptical structure $\sim 16 \mathrm{~km}$-wide in the centre of the island whose origin is still controversial. The caldera is subdivided in three smaller calderas separated in two different parts (Ucanca in the west, and Guajara and Diego Hernández in the centre-east) by the Roques de García spur, which is made of remnant material from Las Cañadas edifice (Fig. 2). The hypothesis about a vertical collapse origin for Las Cañadas caldera proposed by some authors (Araña, 1971; Ridley, 1971) was confronted by the proponents of a lateral landslide origin (Bravo, 1962; Coello, 1973; Navarro and Coello, 1989; Carracedo, 1994; Watts and Mason, 1995; Masson et al., 2002; Teide Group, 1997; Ancochea et al., 1999), who interpreted the caldera walls along its southern and eastern rims as the eroded remnants of the headwall of the Icod landslide-valley detachment fault; the clay-rich volcanic breccia known as "mortalón”, encountered in the water-supply galleries that perforate the Icod Valley, is viewed by those authors as delineating the failure surface of this landslide (see also Márquez et al., 2008), although the existing data do not allow to retrieve an univocal and complete picture of its geometry and specifically of its headwall location. In addition to Icod, La Orotava and Güímar valleys are also recognized as having a landslide origin (Watts and Masson, 1995; Ablay and Hürlimann, 2000; Hürlimann et al., 2004), as well as three other minor valleys (Anaga, East Dorsal and Teno, see Hürlimann et al., 2004 and Figs. 1 and 2).

Other authors have further developed the vertical collapse hypothesis for Las Cañadas caldera, associating the voluminous ignimbrite deposits in the southern part of Tenerife (Bandas del Sur Formation) to the explosive products of different major caldera-forming events in Las Cañadas edifice (Martí et al., 1994; Bryan et al., 1998, 2000; Edgar et al., 2002, 2007). According to Martí et al. (1997) and Hürlimann et al. (1999), both vertical and lateral collapses have interplayed to produce the present structure of the caldera, with some erosion affecting also the relief of the remaining walls. In this view, three different caldera-forming events dated at $1.02,0.57$ and 0.18 Ma produced the overlapping Ucanca, Guajara and Diego Hernández calderas, respectively, delineating an eastward migration of the corresponding magma chambers (see Fig. 2; Martí and Gudmundsson, 2000). These authors propose also a possible trigger of major lateral landslides by caldera collapses and suggest a link between the formation of Guajara and Diego Hernández calderas with La Orotava and Icod valleys, respectively. In this scheme, the headwall of the last major landslide (Icod Valley, $\sim 180 \mathrm{ka}$ ), which is supposed to have eliminated the northern rim of Las Cañadas caldera, is tentatively placed somewhere beneath Teide-Pico Viejo edifices (this is the proposed location shown in Figs. 1 and 2; Hürlimann et al., 2004). Ancochea et al. (1999) presented a different geochronological and conceptual scheme for the constructivedestructive cycles of Las Cañadas Edifice, in which at least two main 


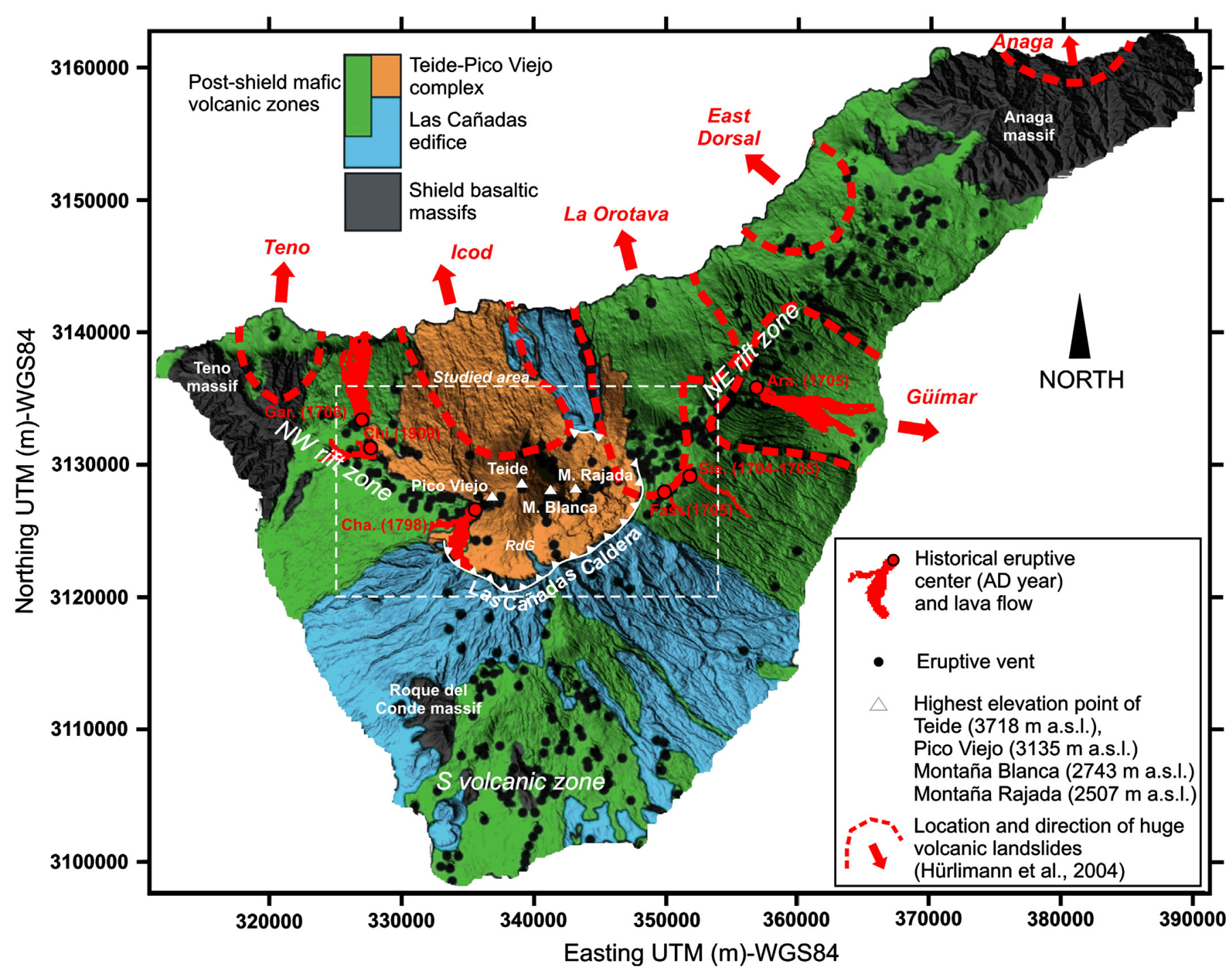

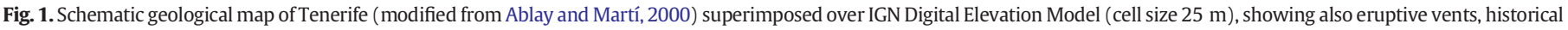
eruptions, proposed structural boundaries due to huge volcanic landslides (Hürlimann et al., 2004) and main central volcanic edifices. RdG is the Roques de García spur.

destructive events are lateral landslides dated at 2.6-2.3 Ma (Cañadas I collapse) and 0.17-0.13 Ma (Cañadas III collapse, forming the Icod Valley and the present Las Cañadas caldera).

In any case, after the last collapse event in the central edifice (either vertical, lateral or both), dated at 0.18-0.13 Ma (Ancochea et al., 1990; Martí et al., 1994; Ancochea et al., 1999; Martí and Gudmundsson, 2000), a new on-going constructive cycle is responsible for the building of Teide (3718 m above sea level, masl) and Pico Viejo (3135 masl) stratovolcanoes in the north of Las Cañadas caldera. These edifices and their numerous flank-vents have emitted mainly basanites, tephrites and phonolites which have filled the Las Cañadas caldera and the Icod Valley (Ablay and Martí, 2000) and which extend also to La Orotava Valley. A trend to more evolved magmas and more explosive activity during this cycle has been described by Martí et al. (2008), similarly to the three previous cycles. The last highly-explosive felsic eruption in the central volcanic complex was that of Montaña Blanca in the southeastern flank of Teide, dated at 2 ka BP (Ablay et al., 1995). The last eruption from Teide summit was that of Lavas Negras, around 0.8-1.15 ka BP (Quidelleur et al., 2001; Carracedo et al., 2007). The last eruption in the central volcanic complex, the Montaña Chahorra or Narices del Teide phono-tephritic eruption, was a historical one (1798 AD) in the southwestern flank of Pico Viejo (Fig. 2).

In addition to this central activity, mafic to intermediate emissions have continued mainly along the Northwestern and Northeastern rift zones during the last $180 \mathrm{ka}$, with some possible minor activity also in the southern basaltic field (Ancochea et al., 1990; Carracedo et al., 2007). During historical times, a few eruptions occurred along the NE and NW rift zones: Fasnia, Siete Fuentes and Arafo in 1704-1705 on the NE rift zone; and Garachico in 1706 and the last one in Tenerife, Chinyero, in 1909 on the NW rift zone (Figs. 1 and 2). In 2004, a seismic crisis occurred in Tenerife, with more than 1000 low-magnitude, mainly onshore earthquakes, clustered in two main groups to the northwest and to the southwest of Teide-Pico Viejo complex (Domínguez-Cerdeña et al., 2011). It has been interpreted by most authors as having a deep magmatic origin (Pérez et al., 2005; García et al., 2006; Gottsmann et al., 2006; Almendros et al., 2007; Gottsmann et al., 2008; Martí et al., 2009; Domínguez-Cerdeña et al., 2011), although it finished without any accompanying volcanic eruption.

\section{Self-potential method}

There are several geophysical methods especially useful to investigate the subsurface structure of volcanic hydrothermal systems, particularly those based on the electrical properties of subsurface materials. Hydrothermal activity in heterogeneous volcanic systems produces very sharp changes in groundwater content and flow direction between different parts of the volcanic system and it also induces strong alteration and argillization of parent volcanic materials. These are primary 


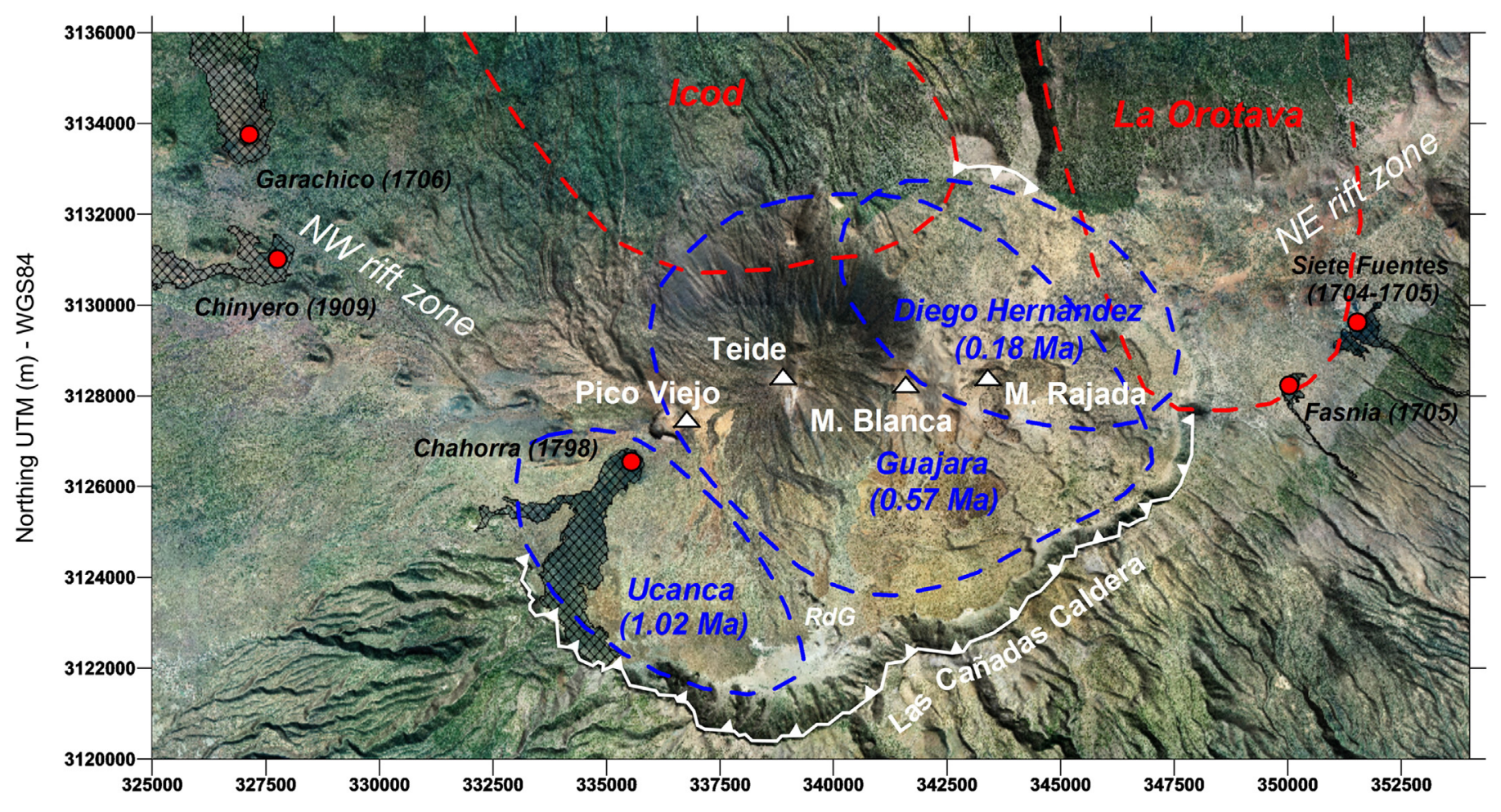

Easting UTM (m) - WGS84
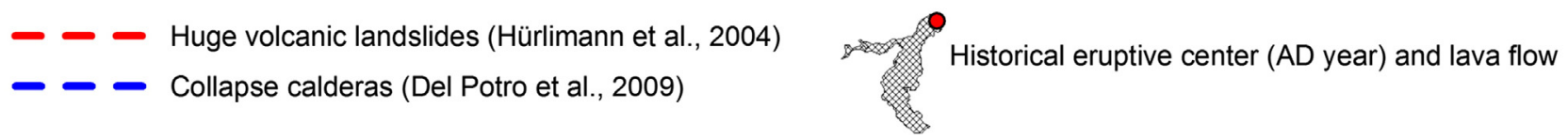

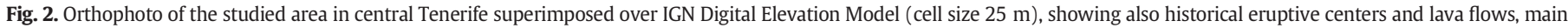

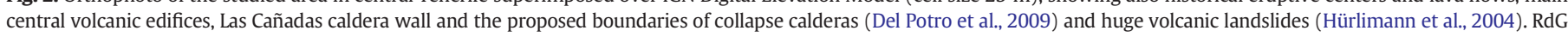
is the Roques de García spur.

factors affecting the electrical resistivity of subsurface materials and the distribution of natural electrical currents and voltages throughout the volcanic edifice. To investigate electrical resistivity distribution, electrical resistivity tomography (ERT) is of prime importance (see Revil et al., 1999a,b, 2004, 2010; Finizola et al., 2006, 2010), but it is an arduous and time-consuming method requiring the mobilization of hundreds of kilograms of instrumentation and water, making very difficult to cover wide areas of rough terrain with enough measurement profiles to extract a complete structural image. The self-potential method, on the other hand, is a passive technique (without any artificial electrical sources), relatively quick and simple to perform and requiring transportation of only few kilograms of material. As Teide-Pico Viejo volcanic complex covers a wide area of rough terrain with a very steep topography, selfpotential method has been chosen as the most adequate to perform an extensive investigation of its hydrothermal systems.

Self-potential signals refer to quasi-static electrical potential anomalies, usually measured at the ground surface of the Earth, that are associated with the occurrence of source current densities at depth (Sill, 1983; Corwin, 1997). The self-potential technique was one of the first geoelectrical methods, developed mainly for metallic ore detection (Fox, 1830), but it was not until the last decades of the 20th century that it experienced a new development in the context of hydrogeological and volcanic studies. On active volcanic areas, theoretical and experimental results have firmly established that the main mechanism responsible for the self-potential anomalies is the electrokinetic coupling, in which the flow of an electrolyte through a matrix of porous rock creates an electrical current (Corwin and Hoover, 1979; Ishido and Mizutani, 1981; Revil et al., 1998, 1999a,b; Ishido and Pritchett, 1999; Revil, 2002; Zlotnicki and Nishida, 2003; Ishido, 2004;
Revil and Jardani, 2013). Where a matrix of silicates is involved, as in volcanic terrains, and for usual groundwater $\mathrm{pH}$ conditions, the groundwater flow drags positive electrical charges and thus creates positive electrical anomalies in the direction of the flow. In this way the distribution of negative and positive self-potential values at the topographic surface is connected to the presence of zones of groundwater recharge or discharge, respectively.

The amplitude and even the polarity of this electrokinetic effect depend on multiple factors like groundwater $\mathrm{pH}$, salinity and temperature. $\mathrm{pH}$ is of special importance, because at the microscopic level the electrical potential created close to the interface between the moving fluid and the rocky matrix (the so called zeta potential) strongly depends on $\mathrm{pH}$. Above a critical $\mathrm{pH}$ value, called the point of zero charge, the zeta potential is negative and the fluid drags an excess of positive electrical charges, as stated in the previous paragraph; below this critical $\mathrm{pH}$ the situation is reversed and the fluid drags negative electrical charges. There are several published studies about the physico-chemical characteristics of central Tenerife groundwater (Farrujia et al., 2001; Soler et al., 2004; Marrero et al., 2008) and all of them show pH values higher than 6.37, electrical conductivities between 140 and $3700 \mathrm{~S} / \mathrm{cm}$ and temperatures between 11 and $37^{\circ} \mathrm{C}$. These $\mathrm{pH}$ values are well above the critical $\mathrm{pH}$ at the point of zero charge usual for silicates (which is $\sim 2-3$, see Revil et al., 1999a) and therefore a negative zeta potential is expected and the groundwater flux will transport an excess of positive electrical charge in the direction of the flow.

Another important consideration refers to the influence of topography on self-potential. In zones where infiltration of meteoric water prevails, positive electrical charges are expected to be dragged towards the local water table, which can be approximated as an equipotential 
surface. If self-potential is measured on the surface of a varying topography, SP minima are expected up-slope, because the distance to the water table (the thickness of the vadose zone) increases, and SP maxima will be measured down-slope, because the distance to the water table decreases. On the contrary, if the measurements are performed in a zone with active hydrothermal systems, in which heat sources produce convection of groundwater, SP maxima will develop where fluid moves towards the topographical surface, that is to say, over the up-going branch of any convective cell, and vice versa (Revil et al., 1999b; Aubert et al., 2000; Zlotnicki and Nishida, 2003; Finizola et al., 2004).

This conceptual scheme serves to interpret the self-potential signal encountered in a wide variety of volcanic systems, where it is very usual to find W-shaped anomalies centered at volcanic edifices which sustain active hydrothermal systems (Nishida and Tomiya, 1987; Matsushima et al., 1990; Nishida et al., 1996; Michel and Zlotnicki, 1998; Zlotnicki et al., 1998, 2008; Ishido and Pritchett, 1999; Finizola et al., 2002, 2003, 2006; Kanda and Mori, 2002; Ishido, 2004; Aizawa et al., 2005; Hase et al., 2005; Ulusoy et al., 2008; Richards et al., 2010; Bennati et al., 2011). The positive anomalies over the edifices are created by the ascending hydrothermal hot fluids, while far away from the volcano summit a negative correlation between topography and selfpotential is observed in the hydrogeological zone. A more or less circular set of self-potential minima delineates the transition zone between the central part dominated by hydrothermal circulation and the outer regions controlled by meteoric water infiltration. In addition, the selfpotential signal will be greatly influenced by structural features like faults and contacts between geological units of contrasting permeability, which can serve as preferential paths for subsurface fluid movement creating additional SP maxima or minima (Byrdina et al., 2013).

Finally, significant lateral variations in the electrical resistivity of subsurface materials can also affect the self-potential values at the surface, since their volume distribution will influence the spatial arrangement of equipotential surfaces. Highly conducting layers or bodies will tend to deform the equipotential surfaces to make them parallel to their boundaries.

\section{Data acquisition and processing}

The self-potential mapping of the active volcanic system of central Tenerife reported in the present work constitutes by its surface extension, by the total longitude of measured profiles $(237 \mathrm{~km})$ and by the number of measurements (11,911 points during seven campaigns between 2007 and 2011), one of the most important efforts of this type performed until now. A spacing of $20 \mathrm{~m}$ between consecutive measurements was chosen to allow enough resolution to detect any linear small-scale feature like faults, resistivity and permeability changes, which can generate SP anomalies with very short spatial wavelengths. Handmade polyvinyl chloride (pvc) and porous wood non-polarizable $\mathrm{Cu}-\mathrm{CuSO}_{4}$ electrodes were employed, as well as commercial high impedance voltmeters and $300 \mathrm{~m}$ cable reels. Alternation of baseelectrode was performed each $300 \mathrm{~m}$ in a leap-frog progression in order to minimize any cumulative error due to inter-electrode off-set. In addition to electrical potential and GPS coordinates (usual precision of $\sim 3-4 \mathrm{~m}$ ), electrical resistance was read at each measuring point as

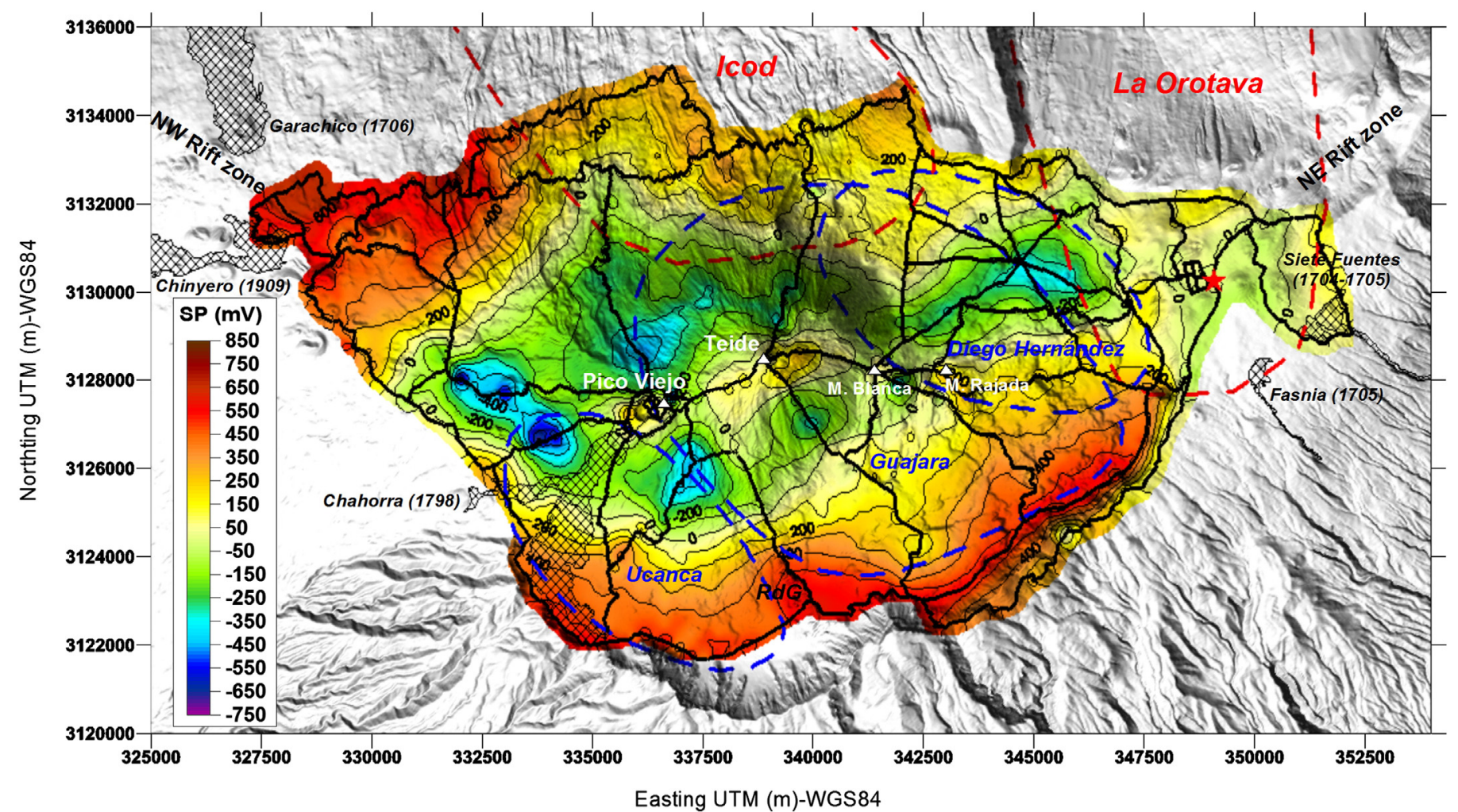

\footnotetext{
- - - Collapse calderas (Del Potro et al., 2009)

- - - Huge volcanic landslides (Hürlimann et al., 2004)

$\sim$ Measured profiles (spacing $20 \mathrm{~m}$ )
}

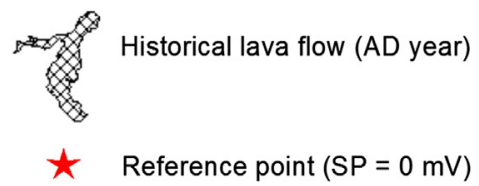

Fig. 3. Self-potential interpolated map (color scale and equipotential lines) superimposed on the shaded relief map of central Tenerife. Historical lava flows, proposed limits of collapse calderas (following Del Potro et al., 2009) and huge lateral landslides (following Hürlimann et al., 2004) are also shown. RdG is the Roques de García spur. (For interpretation of the references to color in this figure legend, the reader is referred to the web version of this article.) 


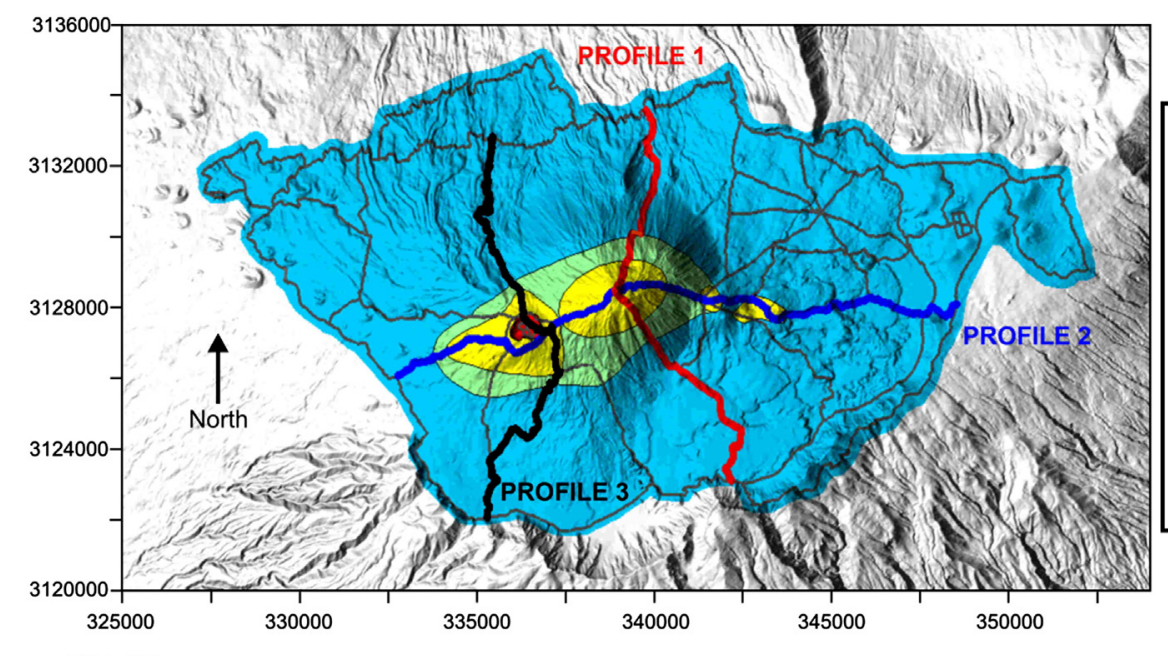

\section{$\underline{\text { Color code }}$}

Summit crater hydrothermal system

Upper hydrothermal system

Lower hydrothermal system

Hydrogeological zone
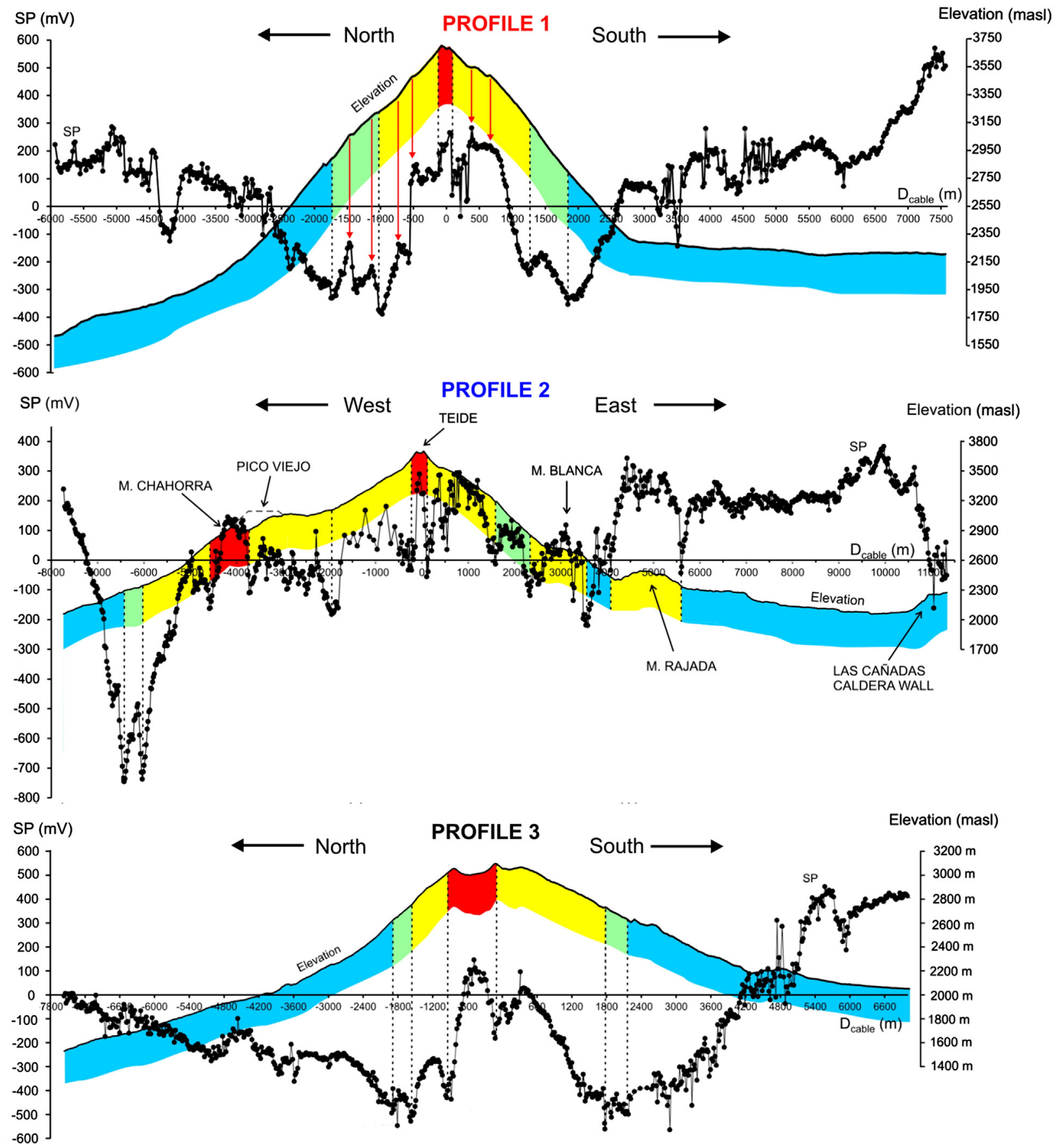
a quick check of the quality of ground-electrode electrical contact and of the eventual necessity of repeating measurements.

An arbitrary reference point outside the Teide-Pico Viejo complex was chosen and all the SP values were referred to it (see Fig. 3). Since the measurements were performed during a significant span of time and with different meteorological and soil-humidity conditions, especial care was taken to close the circuits. Data have been treated for closure-correction in the usual way: an initial closed loop is arbitrarily chosen and its total closure-correction is homogeneously distributed between all its measurements. The closurecorrections of contiguous connecting SP-lines are calculated with respect to this first loop and again homogeneously distributed, and so on. In order to check any possible influence of the arbitrary choice of closure-correction circuits, two different corrections with two completely different sets of circuits have been performed. Essentially the same results are obtained, with just minor changes in the anomaly values but with identical spatial distribution of the anomalies. Relative errors $\left(e_{i}\right)$ for each circuit $(i)$ are calculated from the closure-correction in the following way:

$e_{i}=100 \cdot \frac{E_{i}}{\sum_{j}\left|\Delta V_{j}\right|}, \quad E_{i}=\sum_{j} \Delta V_{j}$

where $E_{i}$ is the closure-correction for circuit $i$ and $\Delta V_{j}$ is the voltage difference between points $j$ and $j-1$ along the circuit. We have retained the set of circuits with the minimum average relative error (3.4\%). For this choice, $29 / 41$ circuits have relative errors below $5 \%, 7 / 41$ between $5 \%$ and $10 \%, 2 / 41$ between $10 \%$ and $15 \%$, the remaining three circuits having relative errors of 17,18 and $25 \%$.

A two-step kriging interpolation (point type, linear isotropic variogram model) has been performed to construct a general SP map from the measured profiles. First, an interpolation with a $200 \mathrm{~m}$ grid was computed; the original data (20 m spacing) were added to this $200 \mathrm{~m}$ grid and a second interpolation with a $50 \mathrm{~m}$ grid was then performed. With this procedure we intend to retain greater resolution along the measured profiles, while trying to avoid the introduction of too much spurious detail in the areas not directly covered by the profiles. The final $50 \mathrm{~m}$ interpolation is restricted to the interior of the outermost circular profile. Although this interpolation procedure minimizes the artificial introduction of spurious short wavelength features in the SP map, it is not able to completely eradicate them; therefore, one has to be careful while interpreting the SP interpolated map and must always have in mind where the measured profiles are located, not placing any significance in short wavelength features observed in areas not covered by those profiles.

\section{Results and interpretation}

The results of the SP mapping are shown in Figs. 3, 4 and 5. Fig. 3 shows the interpolation of the data $(50 \mathrm{~m}$ grid, see the previous paragraph for procedure). Figs. 4 and 5 show the original SP measurements (20 m spacing) along 3 main profiles cutting Teide, Pico Viejo, Montaña Blanca and Montaña Rajada edifices in different directions (Fig. 4) and 3 additional profiles crossing Diego Hernández caldera (Fig. 5).

\subsection{Teide and Pico Viejo self-potential signatures}

The first main outcome of the SP interpolated map is the presence of an elliptical set of SP minima surrounding Teide and Pico Viejo edifices and defining two SP maxima centered at both edifices, partially overlapping and extending in a ENE-WSW direction. This is also clearly observed in the N-S profiles (see profiles 1 and 3 in Fig. 4) crossing both Teide and Pico Viejo edifices, which show the characteristic "W" shape that is commonly associated to active hydrothermal systems in many stratovolcanoes. Profile 2 is more complex due to the superposition of Teide and Pico Viejo anomalies and the presence of additional anomalies that will be discussed below. Considering the differences between the summit values and the minimum values at the flanks of the edifices, the total relative SP anomalies associated to hydrothermal activity amount to approximately $+600 \mathrm{mV}$ in Teide and $+700 \mathrm{mV}$ in Pico Viejo.

Outside Teide and Pico Viejo edifices a general negative correlation between the SP signal and the elevation along the profiles indicates that we enter the hydrogeological zone, where the SP signal is mainly controlled by the vertical distance to the local water table (the thickness of the vadose zone) and the downward infiltration of meteoric groundwater. The limit between the hydrogeological zone and the hydrothermal zone is delineated by the SP minima where the negative correlation between SP and topography breaks down and where a first clear increase in SP with topography is detected (main SP minima in Fig. 3). This limit is observed in the whole set of radial profiles extending from Teide and Pico Viejo summits, where the SP variation clearly reverses going downslope: from the summits of Teide and Pico Viejo volcanoes to their bases, the SP values decrease until they suddenly begin to increase, while the altitude continues to decrease (this is illustrated perfectly in Profiles 1 and 2 of Fig. 4). Joining the limits in the different radial profiles, an estimation of the surface extension of the hydrothermal zone is obtained (see maps in Figs. 4 and 5 and interpretative map in Fig. 6).

The SP signal inside the hydrothermal zone (Fig. 4) reveals very interesting details superimposed to the general "W" shape, with two successive sets of relative SP maxima in the middle and upper flanks of Teide and Pico Viejo edifices and a third strong positive peak in the summits. The first set of small SP maxima is observed in the middle parts of Teide (very clear) and Pico Viejo (less clear) flanks. These anomalies represent the first departure from the purely hydrogeological, negative SP-elevation correlation and therefore constitute the first manifestations of hydrothermal activity. They define what we have classified as "lower hydrothermal systems" of Teide and Pico Viejo edifices (green zones in Figs. 4, 5 and 6). At higher altitudes, a second, stronger set of positive SP maxima indicates the effects of the "upper hydrothermal systems", covering the central parts of the main edifices (yellow zones in Figs. 4, 5 and 6). Additional strong increases in SP values are observed inside the summit craters of Teide and Pico Viejo, defining the "summit crater hydrothermal systems" (red zones). In Pico Viejo, this summit crater hydrothermal system extends to the southwest covering the zone between the crater and the main vents of Montaña Chahorra eruption, occurred in $1798 \mathrm{AD}$. This seems to indicate that remanent hydrothermal activity is associated to the feeding system of M. Chahorra historical eruption, as well as to the principal conduits of Teide and Pico Viejo edifices.

This subdivision of the hydrothermal system in three concentrical sub-systems is a practical way to describe them, and it is very clear in the case of the summit craters of both Teide and Pico Viejo edifices. It is also clear in the south face of Teide and the north face of Pico Viejo, but it is more speculative in the north face of Teide, where more than three relative SP maxima occur, and the south face of Pico Viejo, where the lower SP maxima is small and obscured. It is also more tentative in the east-west transect, that is complicated by the superposition of the effects of both Teide and Pico Viejo systems, as well as the flank vents of Montaña Blanca and Montaña Rajada to the southeast.

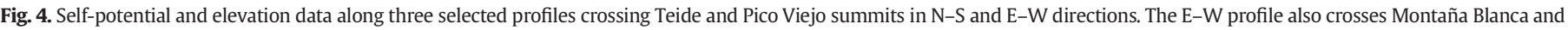

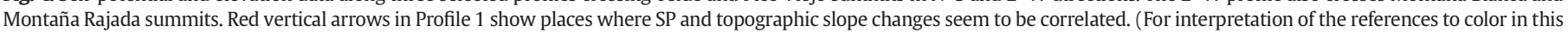
figure legend, the reader is referred to the web version of this article.) 

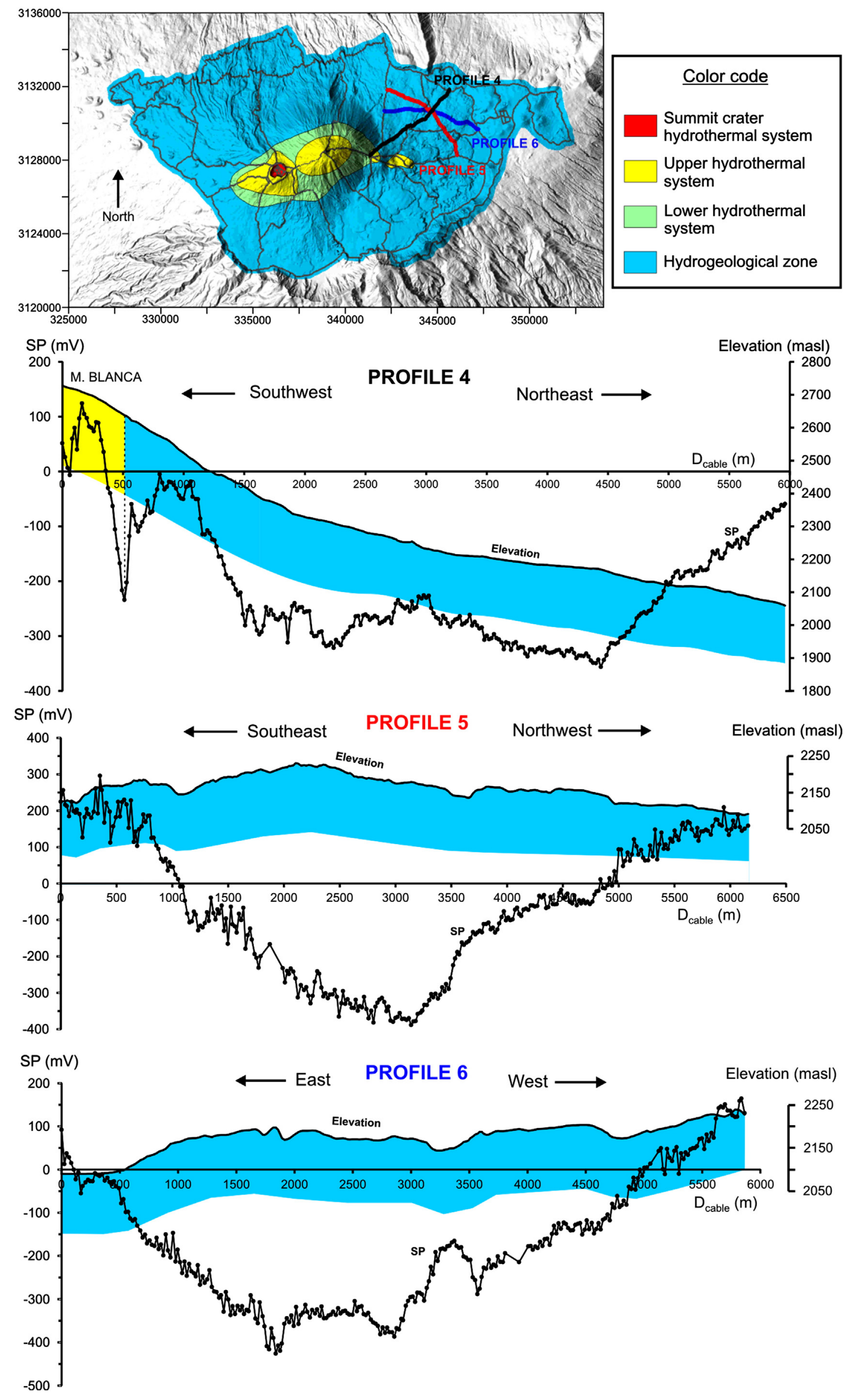


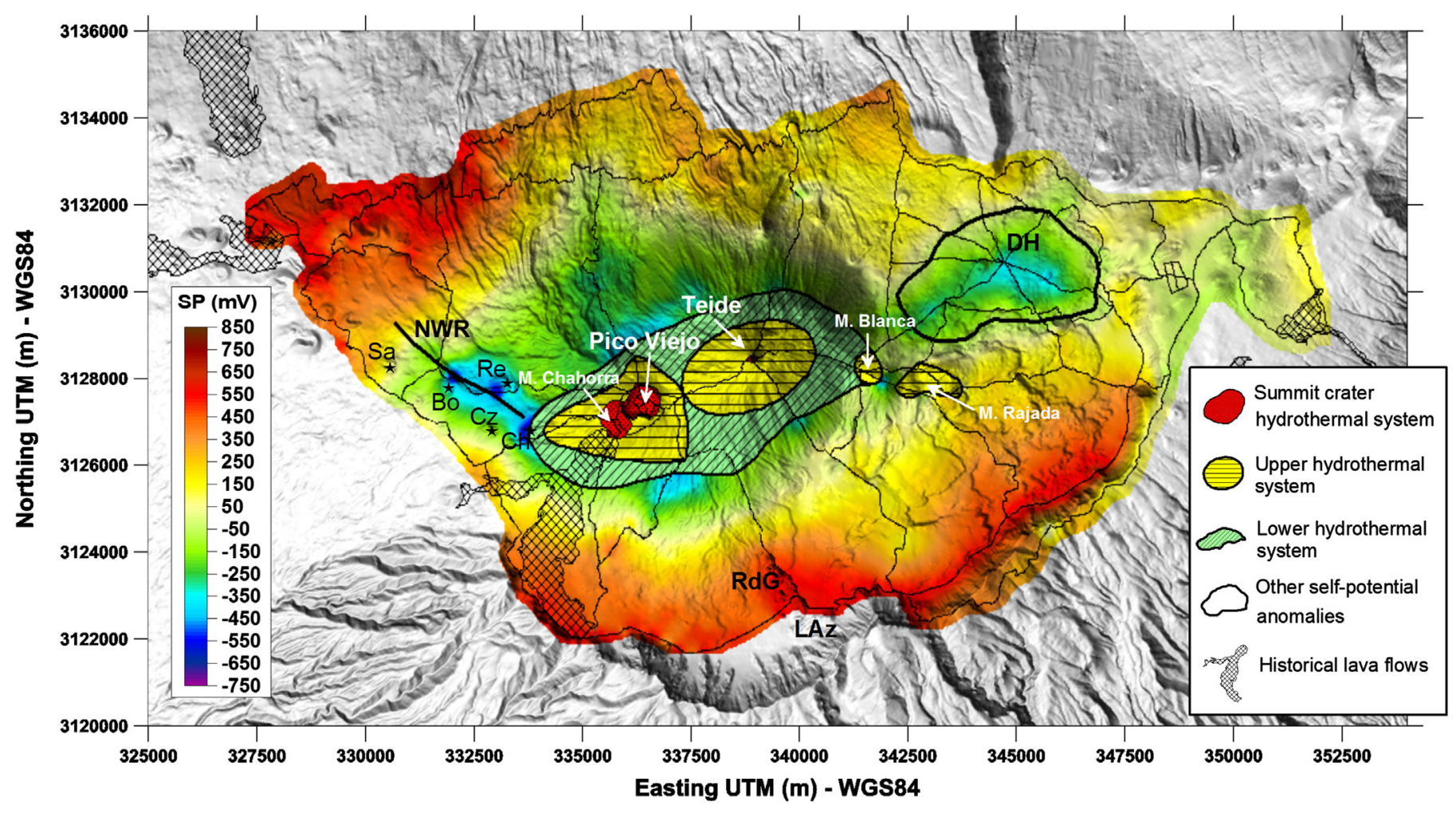

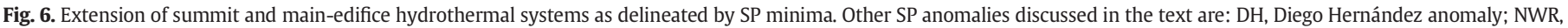

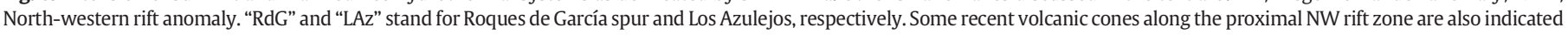
with black stars: Ch, Montaña de Chío; Re, Montaña Reventada; Cz, Montaña de la Cruz de Tea; Bo, Montaña Botija; Sa, Montaña Samara.

The behavior of the SP signal inside the hydrothermal zone is correlated with obvious topographic features such as the presence of the summit craters. At some points of Teide edifice, especially in its north and south faces, SP seems also to be correlated with changes in topographic slope (see vertical red arrows in Fig. 4, profile 1). All this suggests a strong influence of subsurface structural boundaries on the SP signal, indicating the existence of preferential paths for hydrothermal fluids upward migration and/or meteoric groundwater downward infiltration. Nevertheless, the detailed analysis of the inner structure of the hydrothermal zones, the structural significance of the mentioned correlations and the interpretation of the tentative subdivision of the hydrothermal system in three subsystems clearly need a deeper study and will be treated in a separate paper; in the present work we aim to concentrate in the delineation of the main SP zones and the total surficial extent of the detected hydrothermal systems.

\subsection{Self-potential signature of flank satellite edifices}

As can be observed in the interpolated map (Fig. 3) and more clearly in Profile 2 (Fig. 4), there are two additional positive SP anomalies centered over Montaña Blanca $(+240 \mathrm{mV})$ and Montaña Rajada $(+380 \mathrm{mV})$ edifices, on the eastern-southeastern flank of Teide. These anomalies can also be observed in all the profiles radiating from these two secondary edifices, indicating the presence of hydrothermal systems at both edifices and permitting us to delineate their extension. No clear inner structure of these hydrothermal systems is observed in the data, therefore we have arbitrarily classified them as "upper hydrothermal systems" (yellow color in Figs. 3, 4 and 5). The SP signal of these hydrothermal systems is much weaker than that of Teide and Pico Viejo, and no surface manifestation like fumaroles is observed neither in M. Blanca nor in M. Rajada. Additional measurements like thermal IR imagery should be taken to confirm or deny the presence of thermal anomalies and active hydrothermal systems, like in other sites where satellite edifices have been associated with a local hydrothermal system (e.g. Formica Leo strombolian cone on Piton de la Fournaise volcano; Antoine et al., 2009), but the previous facts rise also the possibility of interpreting M. Blanca and M. Rajada hydrothermal systems as fossil systems, following the work of Ishido (2004), who modeled weak positive SP anomalies over fossil hydrothermally altered volcano cores with roots in contact with the water-saturated layer. SP data by themselves are not able to discriminate between active or fossil hydrothermal systems for M. Blanca and M. Rajada. All the information about the extension and structure of the hydrothermal systems is summarized in Fig. 6, where the different hydrothermal zones are shown over the SP interpolated map by means of a color zonation.

\subsection{Las Cañadas caldera}

The second main feature observed in our SP data is the elliptical negative anomaly in Diego Hernández caldera (DH in Fig. 6). Three different profiles crossing this caldera are represented in Fig. 5. The SP behavior in this area strongly departs from the expected topographic effect (see especially Profile 4, where the strongest variation of topography inside Diego Hernández is observed) and instead it seems to delineate a funnel-shaped anomaly potentially related to the buried caldera floor geometry. This point will be treated extensively in the Discussion section of this work. What we can conclude from the SP map is that the hydrogeology of the three calderas comprising the broader Las Cañadas 
caldera (Diego Hernández, Guajara and Ucanca) seems to be different: Diego Hernández caldera presents a strong, almost closed negative anomaly, with SP negative values subtly extending to the head of La Orotava Valley probably indicating outflow of groundwater towards the valley; Guajara and Ucanca calderas show small and positive SP values, with their limits defined to the south by the positive values observed near the Las Cañadas caldera walls and giving way to the north to the superimposed effects of Teide-Pico Viejo hydrothermal systems. Guajara and Ucanca seem to be separated by strong positive SP values in the Roques de García area, suggesting separate groundwater systems, but the SP signal from Teide and Pico Viejo makes it impossible to follow this limit further north. The overall SP behavior suggests separate hydrogeological systems in Diego Hernández, Guajara and Ucanca calderas, although the separation between the two last is more tentative. The SP mapping includes many profiles over Diego Hernández, but less measurements were performed at Guajara and Ucanca and therefore any interpretation of the results in the two western calderas will be much less detailed.

Positive SP values are observed to the south of Las Cañadas caldera floor, close to its walls. These values result mainly from the topographic effect and the decreasing thickness of the vadose zone, but in some profiles the increase in SP seems to exceed what would be expected from the change in elevation (see for example Profile 1 in Fig. 4). This is probably related to the existence at shallow depths of hydrothermally altered material, which has higher electrical conductivity than nonaltered volcanic products and therefore produces a positive relative anomaly above its shallower parts. The existence of hydrothermal alteration along some parts of the southern caldera walls has been previously documented, especially at Los Azulejos area close to Roques de García spur (Galindo et al., 2005; see Fig. 6). It is also expected that after the caldera forming events, preferential fluid migration will be produced along its rims, favoring hydrothermal alteration.

\subsection{The rift zones}

A third remarkable result from the SP mapping is the presence of a quasi-linear negative anomaly to the west-northwest of Pico Viejo, extending in the direction of the Northwestern rift zone (NWR anomaly in Fig. 6). This anomaly coincides with a similar lineation of recent, mafic to intermediate volcanic cones (M. de Chío, M. de la Cruz de Tea, M. Reventada, M. de la Botija, M. Samara, see locations in Fig. 6) which represent the recent activity of the NW rift along its closest part to Teide-Pico Viejo complex, reaching the lower flanks of Pico Viejo. Fracturing and dyke injection are presumably high in this zone, and therefore the linear negative SP anomaly is readily explained by preferential strong meteoric groundwater infiltration along this NW-SE system of fractures and permeability contrasts. If this explanation is correct, one could wonder why this negative SP anomaly is abruptly interrupted to the NW, providing that fractures and dykes must be also present along the rest of the NW rift, not only where the negative anomaly is found. We can suggest that further to the NW the topographic effect and the proximity to higher water table levels (see next paragraph) take control over the SP signal and produce positive SP values that obliterate the negative anomaly. Another explanation could be that the NW rift fracture system itself, for some reason, is more developed or more permeable in its closest part to Pico Viejo, maybe because of differences in the rheological/hydrogeological properties of the rocks of Pico Viejo edifice itself, comparing with the host rocks of the rest of the NW rift, or because of differences in the stress field pattern.

Positive SP values are also present in the NW part of the map, over the NW rift zone. This behavior is again readily explained by the topographic effect, because in this area there is a clear decrease in elevation, in addition to a relatively high altitude of the water-table caused by the existence of a dense net of non-permeable dykes that significantly decreases the terrain permeability in the direction perpendicular to the rift axis (Plan Hidrológico Insular de Tenerife, 2013). To the NE, over the proximal NE rift zone, no SP anomalies are detected. These two facts imply that, according to the SP data, there is no evidence of significant hydrothermal activity along the two main rift systems at the present time.

\subsection{Icod Valley}

To the north of the SP map (Fig. 3), in the Icod Valley, SP values do not increase significantly, although there is a strong decreasing trend in elevation. This implies a more or less constant thickness of the vadose zone, in other words, the bottom of the vadose zone runs approximately sub-parallel to the topography. This behavior is clearly consistent with the origin of the Icod Valley as a lateral landslide and with the presence at depth of the clayey volcanic breccia known as "mortalón", which delineates the failure surface of the landslide and which forms a strong permeability contrast that determines the geometry of groundwater migration. As shown in Fig. 3, the western lateral boundary of the Icod Valley suggested by the SP data (yellow to orange-red transition in Fig. 3) compares quite well with the western limit proposed by Hürlimann et al. (2004) for the Icod landslide.

The above-presented interpretation of the main features of the SP mapping is summarized in Figs. 6 (orthographic view) and 7 (3D view). Obviously, the subsurface geometry and depth assigned to the different hydrothermal systems is completely arbitrary and has been chosen solely for graphical representation purposes. The SP method, which is based on natural sources and does not imply the injection of any artificial electric current, does not allow a univocal quantitative estimation of the depth of the electrical sources, although some qualitative insight can be gained from the characteristic wavelengths of the different anomalies. The fact that Teide and Pico Viejo SP positive anomalies are wide (in the $\mathrm{km}$ range) implies that the respective hydrothermal systems have significant lateral extension and depth.

\section{Discussion}

Once the main features revealed by the SP mapping have been presented, some additional insights about their significance can be gained comparing them with the results of previously published geophysical studies.

\subsection{SP vs. gravimetry}

Several papers have documented a low gravity anomaly over the central part of Teide-Pico Viejo complex, interpreting it as due to the relatively low densities of the evolved phonolitic lavas and pumices erupted during the last constructive phase of Las Cañadas Edifice (Ablay and Keary, 2000; Araña et al., 2000). This gravimetric anomaly is associated with an aeromagnetic negative anomaly, interpreted by Araña et al. (2000) as resulting from either the relatively low magnetizations of the evolved phonolitic materials when compared to mafic materials, or to a loss of magnetization due to significant hydrothermal alteration inside Teide and Pico Viejo edifices. Nevertheless, the resolution of these works was low because of lack of sufficient data-points or because their modeling strategies were aimed to understand the general, deep structure of the island and not its shallower parts. A significant increase in the number and density of gravity measurements and a more powerful modeling approach was reported by Gottsmann et al. (2008). These authors confirmed the low gravity anomaly over Teide, Pico Viejo and Montaña Blanca edifices, and modeled the subsurface density structure responsible for it. In Fig. 8A, the modeled density contrast at $2000 \mathrm{~m}$ above sea level is represented over a shaded relief map of central Tenerife, calculated as a deviation from a homogeneous density medium (Gottsmann et al., 2008). The negative density anomaly modeled below Teide, Pico Viejo and Montaña Blanca edifices extends downwards to around $0-1000 \mathrm{~m}$ below sea level, according to the 


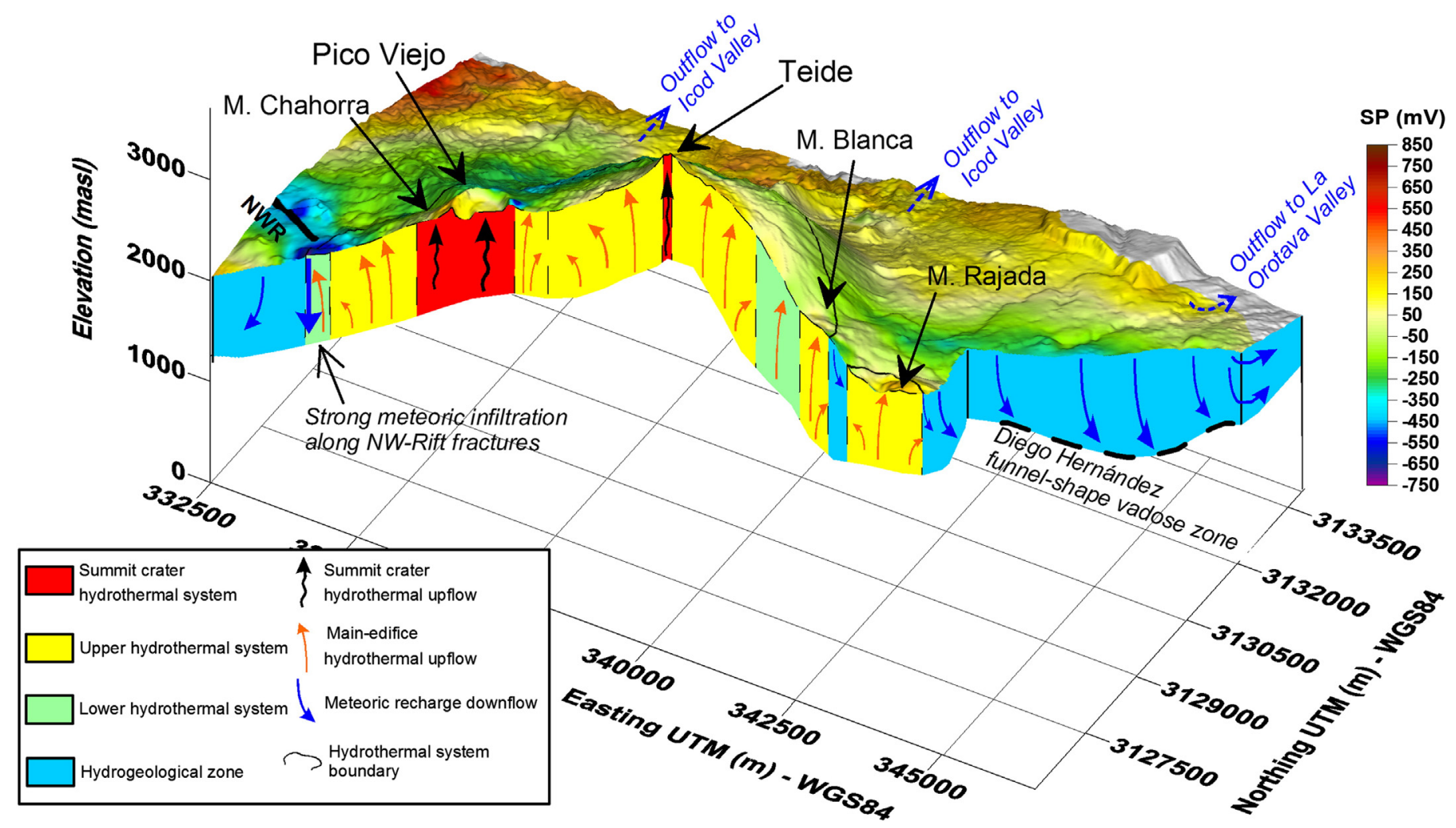

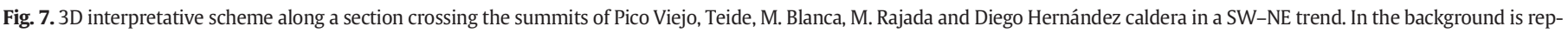

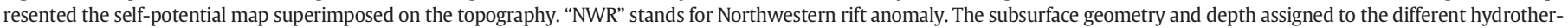
mal systems is completely arbitrary and has been chosen solely for graphical representation purposes.

authors. Gottsmann et al. (2008) interpreted this anomaly as resulting from both the lower inherent density of phonolitic materials and to significant hydrothermal alteration of Teide, Pico Viejo and Montaña Blanca edifices. Since petrological evidence indicates the existence of shallow magmatic chamber/chambers below Teide and Pico Viejo at depths around or slightly below sea level (1-3 km bsl at the most) (Ablay et al., 1998; Triebold et al., 2006; Andújar et al., 2010), Gottsmann et al. (2008) suggested that hydrothermal alteration has affected almost the whole volcanic pile constructed above these magma chambers, from their top up to the terrain surface.

We have chosen the 2000 masl horizontal section of their density contrast model to compare with our SP data because it is the highest section available in Gottsmann et al. (2008); in addition, its altitude approximately coincides with the altitude of Las Cañadas Caldera floor and all the SP data pertaining to the hydrothermal systems of Teide, Pico Viejo, Montaña Blanca and Montaña Rajada edifices were measured at higher topographic altitude. The SP interpolated map is again represented in Fig. 8B, where we have included also the outer limits of the lower and upper hydrothermal systems described above. These boundaries have been plotted also over the 2000 masl section of the density contrast model of Gottsmann et al. (2008) in Fig. 8A to facilitate the comparison between both data-sets. As can be seen, there is a striking coincidence between the estimated extension of the hydrothermal systems deduced from SP measurements at the terrain surface and the modeled negative density anomaly close to the surface. There is also a very good correlation between the position of the transition zone between Teide and Pico Viejo upper hydrothermal systems, as deduced from SP data, and a neutral density zone which separates the negative density anomalies below Teide and Pico Viejo edifices at the 2000 masl section. The close correlation between these two independent data sets places strong confidence in the interpretation of gravity and aeromagnetic anomalies below Teide-Pico Viejo system as resulting from a high degree of hydrothermal alteration of both edifices.
Although the coincidence is not so good, below Montaña Blanca edifice there is also a negative density anomaly, related to a SP positive anomaly which defines a hydrothermal system slightly displaced to the north (with respect of the density anomaly). Regarding Montaña Rajada hydrothermal system, revealed also by SP data, there is not any clear associated negative density anomaly in the model of Gottsmann et al. (2008). The discrepancies between both data sets observed for these two secondary edifices, which have much more reduced dimensions than Teide and Pico Viejo, are probably due to the too-sparse gravity data coverage, which do not allow precise comparisons at this level of detail.

\subsection{SP vs. magnetotellurics}

The magnetotelluric and audiomagnetotelluric study of Pous et al. (2002) detected the existence of two main layers inside Las Cañadas caldera: an upper resistive layer corresponding to the vadose unsaturated zone and a lower conductive layer corresponding to the water saturated zone of Las Cañadas hydrogeological system. The results pointed to the presence of three different hydrogeological systems in the three Las Cañadas calderas (Ucanca, Guajara and Diego Hernández), corresponding to different infillings and topographies of the bottom of the calderas. The authors reported also an apparent gradual deepening of the water table level at Diego Hernández towards the head of La Orotava Valley, suggesting that Diego Hernández caldera is open to the NE or somehow connected to La Orotava Valley. This work detected also the presence of a shallow conductor at the feet of the southern-southeastern caldera walls, suggesting it as a result of fossil hydrothermal alteration along the strongly fractured border of the caldera.

These results were confirmed and refined in the extensive audiomagnetotelluric (AMT) study of Coppo et al. (2008), who also modeled the subsurface electrical resistivity structure of the eastern half of Las Cañadas caldera with two main layers, an upper resistive 


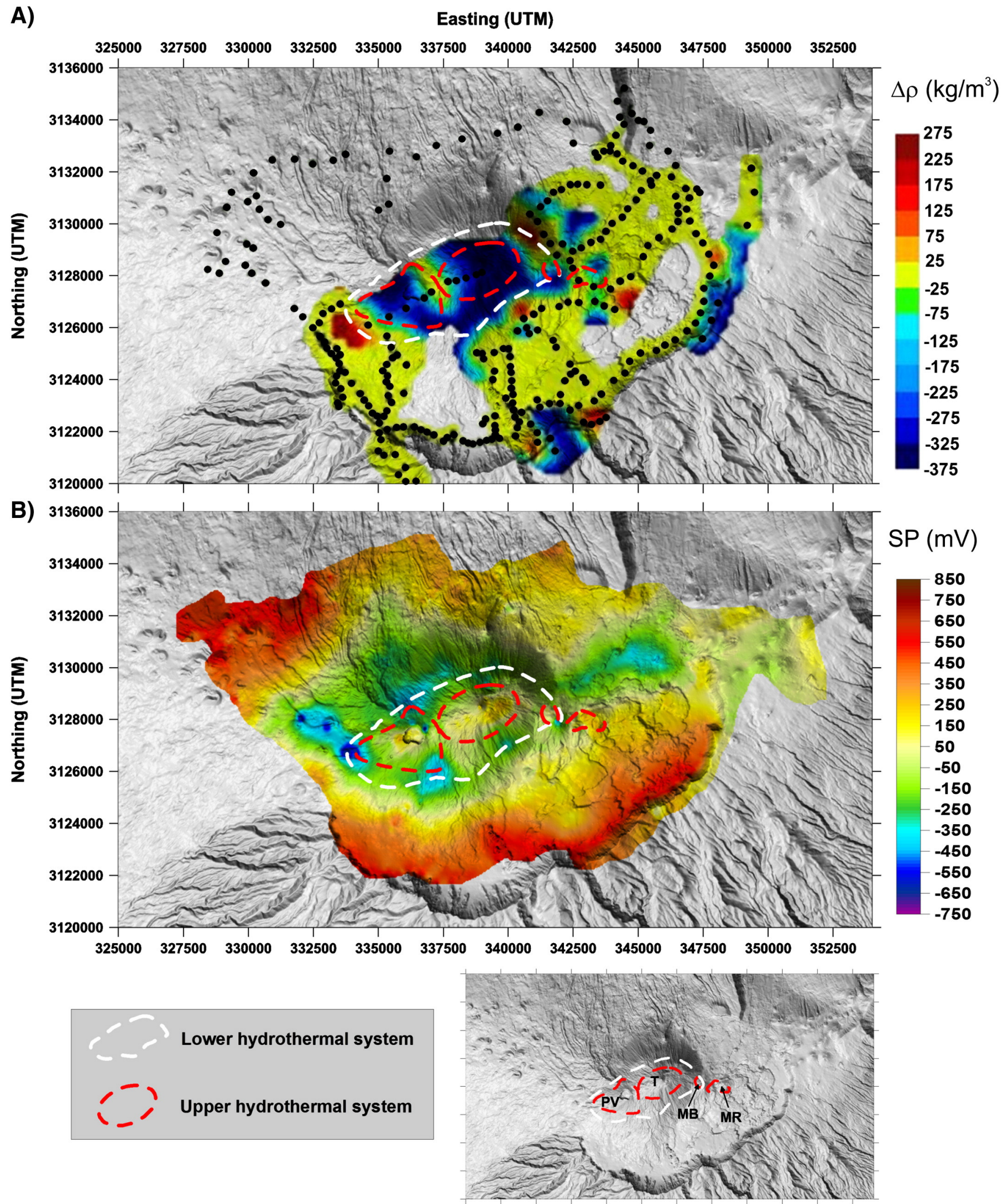

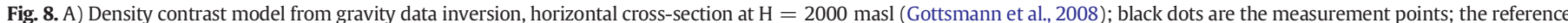

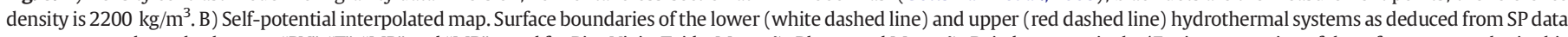

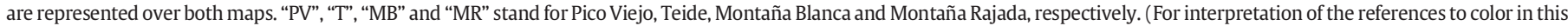
figure legend, the reader is referred to the web version of this article.) 

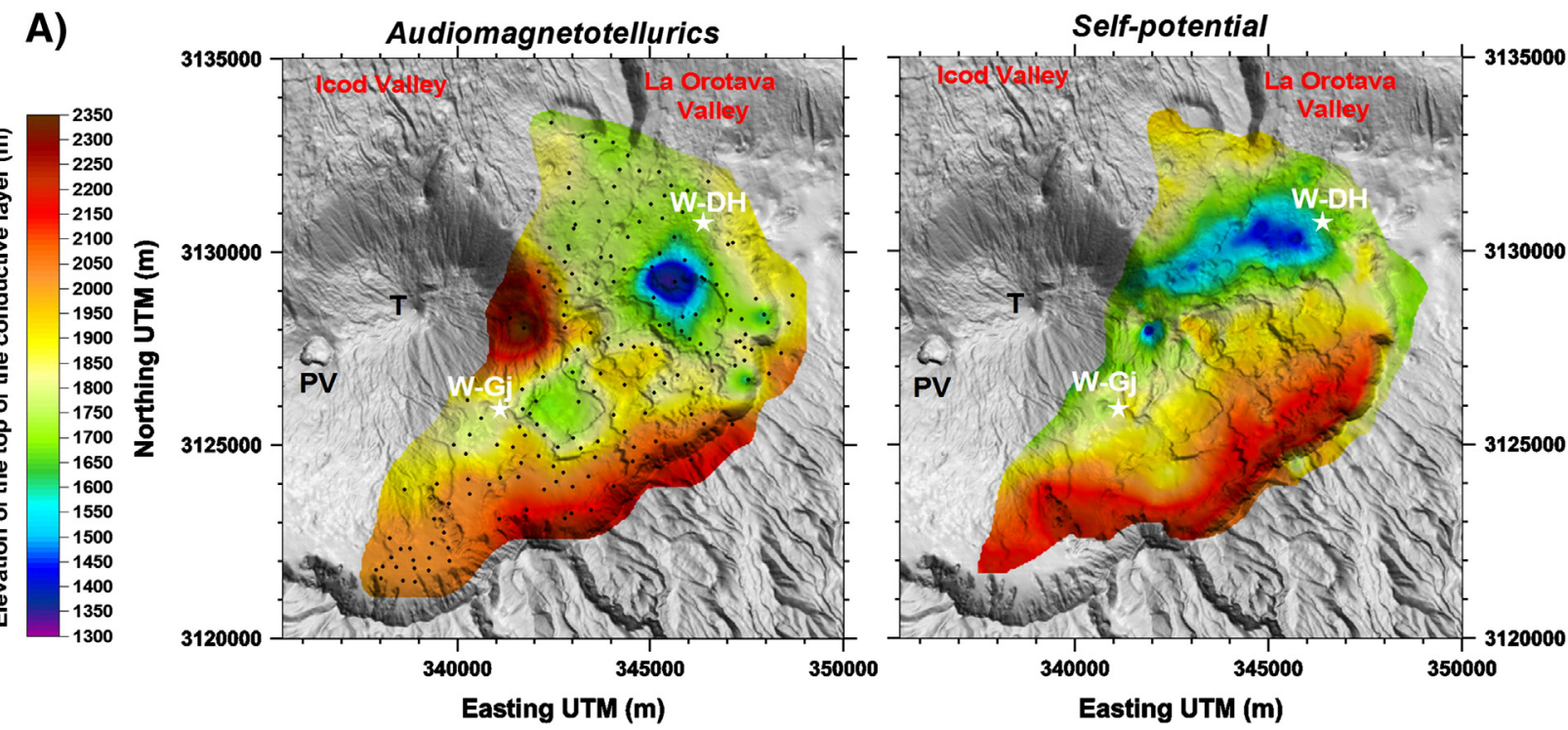

B)

\section{C)}
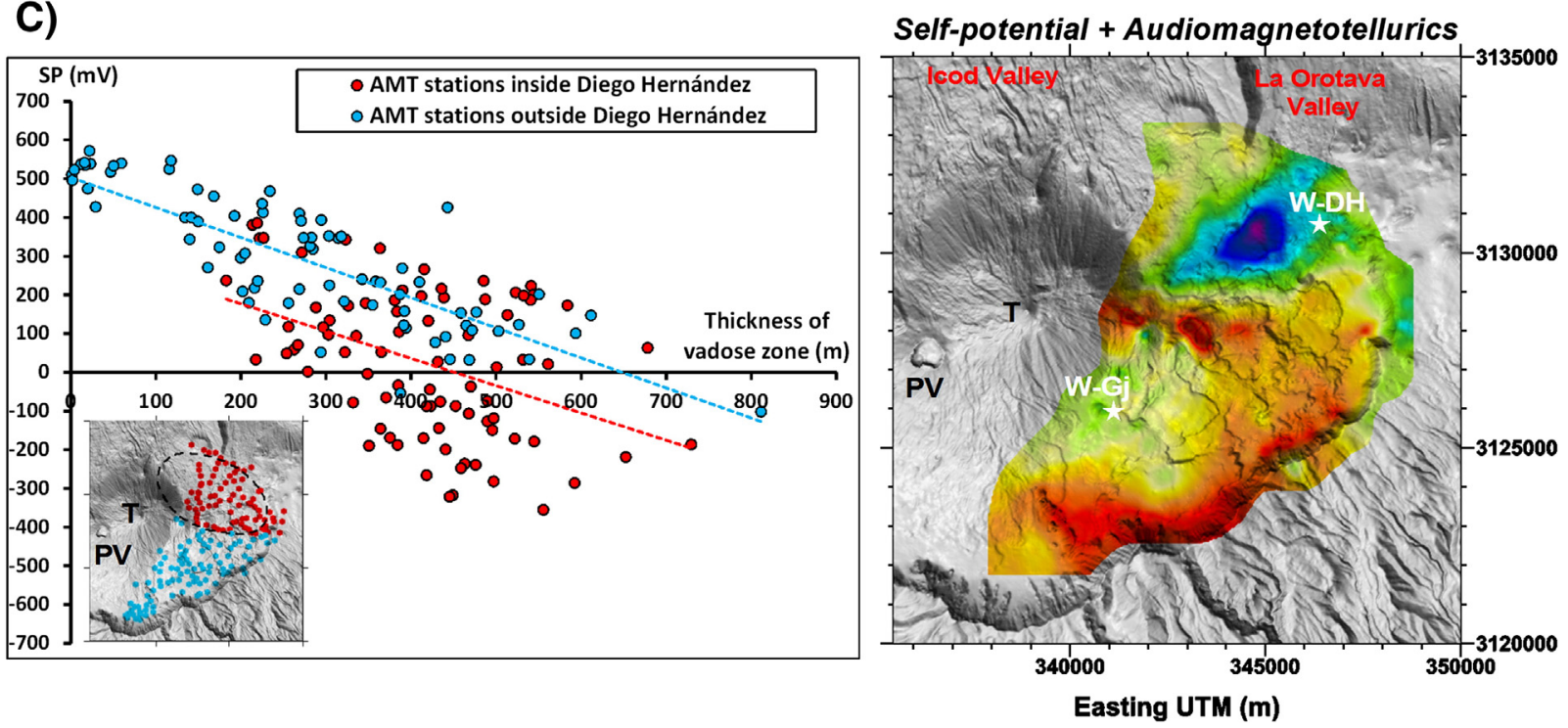

D)

$-2450$

$-2400$

2350
-2300

2250

$-2200$

2100

$-2050$

2000

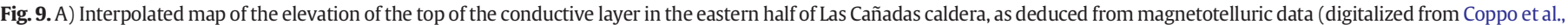

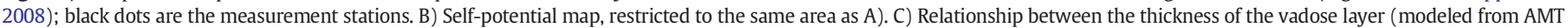

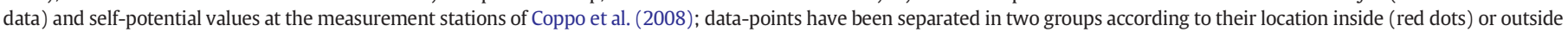

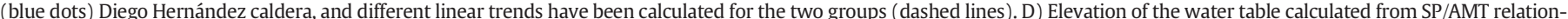

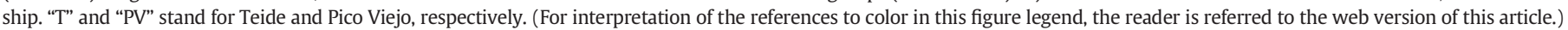

vadose layer, and a lower conductive water-saturated layer. Their dense data coverage allowed them to estimate the subsurface topography of the boundary between both layers much better than Pous et al. (2002). This topography, expressed as the elevation above sea level of the top of the lower conductive layer, can be seen in Fig. 9A. To draw this map, the contour lines of the original Fig. 9 of Coppo et al. (2008) have been digitalized and a new grid has been calculated from them. Coppo et al. (2008) agreed with Pous et al. (2002) about the existence of different calderas inside Las Cañadas, with Diego Hernández, Guajara and Ucanca showing different and independent subsurface structures. These authors interpreted the topography of the top of their lower conductive layer as a tracer of the topography of the bottom of each caldera. Their results compare quite well with the SP results obtained in the present work, which can be seen again in the interpolated map of Fig. 9B, restricted to the same area covered by Coppo et al. (2008) and with an adapted color scale. Focusing on Diego Hernández caldera, Coppo et al. (2008) mapped a funnel-shape subsurface topography resembling the SP mapping results, but with a much more circular geometry and with its minimum displaced slightly to the south of the SP minimum. SP negative values, on the other hand, seem to subtly extend to the head of La Orotava Valley, a feature that is less evident in the data of Coppo et al. (2008).

In addition to this qualitative comparison, a quantitative approach has been intended. In the eastern half of Las Cañadas Caldera there are two deep wells perforated and monitored by the Consejo Insular de Aguas de Tenerife (Tenerife's water management public authority; see Farrujia et al., 2001, 2004, 2006), located at Montaña Majúa and El Portillo in the Guajara and Diego Hernández calderas, respectively (see "W-Gj" and "W-DH" with the white stars in Fig. 9). Therefore, a first step has been to compare the elevation of the top of the watersaturated layer modeled by Coppo et al. (2008) at the two wells with the real water-levels directly measured at both points during the time Coppo et al. (2008) performed their AMT measurements. The modeled and measured elevations of the water table are shown in Table 1. As can be seen, Coppo et al. (2008) model seems to have an average constant offset of $-118.5 \mathrm{~m}(-124 \mathrm{~m}$ at W-DH and $-113 \mathrm{~m}$ at $\mathrm{W}-\mathrm{Gj}$ ), which is remarkably small, and their model gives the correct difference in water-table level between both calderas (around 60-70 m 
Table 1

Real and modeled water table levels at two wells inside Las Cañadas caldera.

\begin{tabular}{|c|c|c|c|c|c|}
\hline \multicolumn{6}{|c|}{ Elevation of the water table (masl) } \\
\hline Well & Location & Measured $^{\mathrm{a}}$ & Audiomagnetotellurics $^{\mathrm{b}}$ & Corrected audiomagnetotellurics ${ }^{\mathrm{c}}$ & Self-potential $^{\mathrm{d}}$ \\
\hline W-DH & El Portillo & 1756 & 1632 & 1750 & 1418 \\
\hline W-Gj & M. Majúa & 1818 & 1705 & 1823 & 1669 \\
\hline
\end{tabular}

a Farrujia et al. (2006).

b Interpolated from Coppo et al. (2008) digitalized data.

c Corrected from digitalized data of Coppo et al. (2008).

d Interpolated from SP data after correlation with Coppo et al. (2008).

lower in $\mathrm{W}-\mathrm{DH}$ than in $\mathrm{W}-\mathrm{Gj}$ ). Thus, a constant correction of $+118.5 \mathrm{~m}$ has been applied to the grid obtained from Coppo et al. (2008), to approximate it as much as possible to direct measurements.

In purely hydrogeological zones, SP values are strongly (but not exclusively) controlled by the vertical distance between the measurement point and the water table, in other words, by the local thickness of the vadose zone. From the corrected data of Coppo et al. (2008) a very good estimation of this thickness can be obtained just subtracting the corrected elevation of the lower conductive layer from the topography. The thickness of the vadose zone and the SP interpolated value have been computed for each of the original measurement points of Coppo et al. (2008). Both variables have been plotted in Fig. 9C, dividing the points in two subsets, those inside or very close to and those outside
Diego Hernández caldera, taking the boundary of the caldera from Del Potro et al. (2009). If the water-saturated layer is assumed to be a perfect conductor which has accumulated the excess positive electrical charge transported by meteoric water infiltration downwards through the vadose zone, then the electrical potential at the terrain surface could be approximated as a linearly decreasing function of the thickness of the vadose zone. Fig. 9C shows a clear decreasing, although poorly linear, trend of SP values with the thickness of the vadose zone, and a linear adjustment has been calculated for each sub-set of points. These two linear functions have been subsequently applied to the interpolated SP map of Fig. 9B in order to transform the SP map into a map of the elevation of the water-saturated layer. The result is shown in Fig. 9D in orthographic view and in Fig. 10 in a 3D view from the northeast. On these

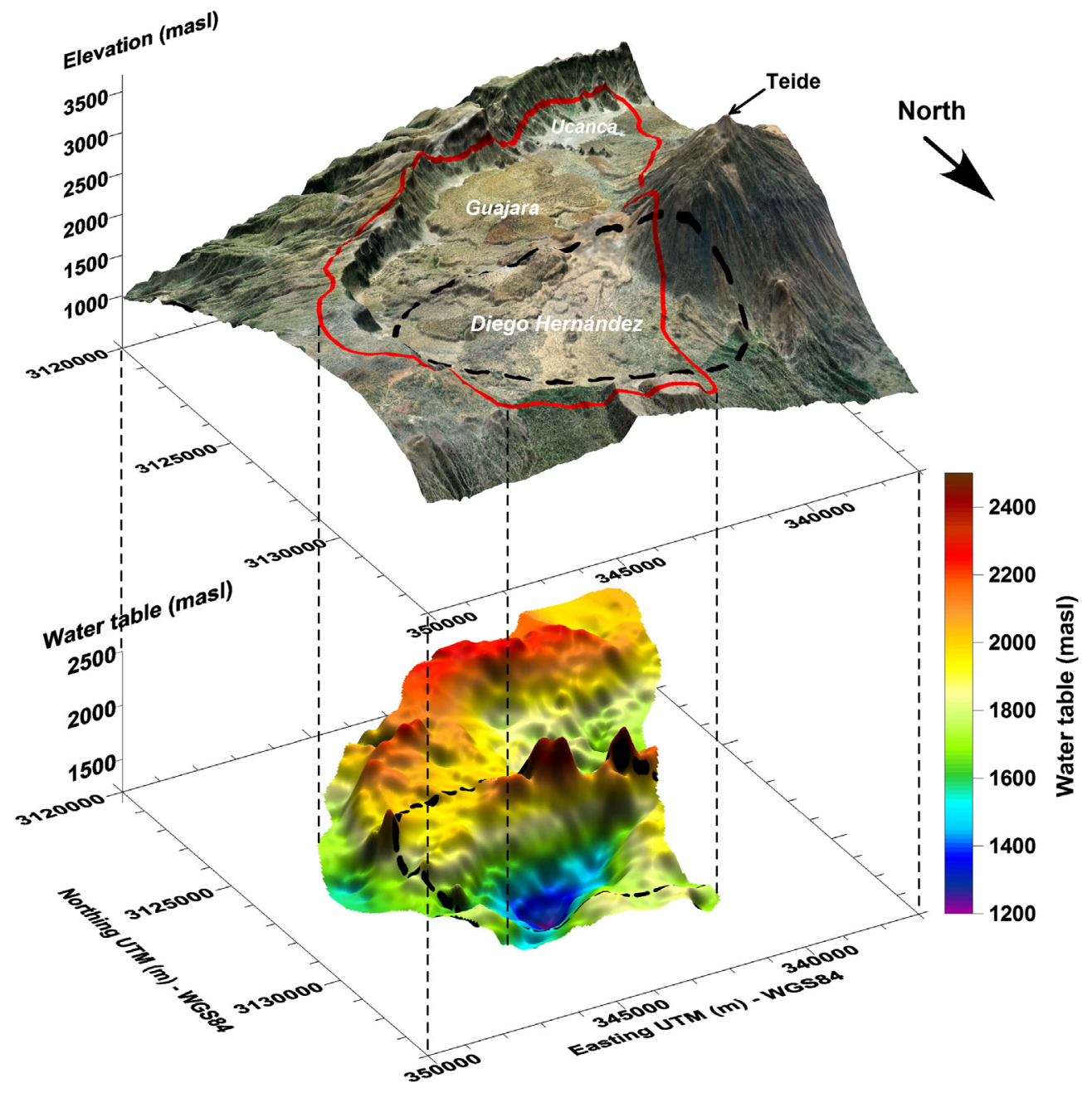

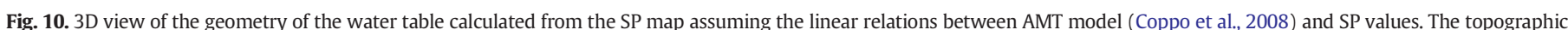

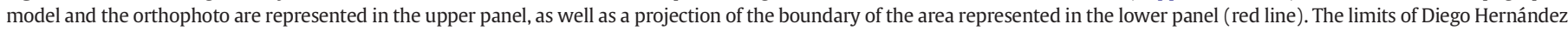

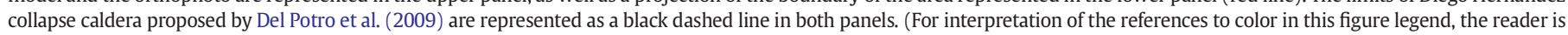
referred to the web version of this article.) 
figures, the boundary between Guajara and Ucanca calderas is also evidenced. The SP data indicate also a clear deepening trend of the watersaturated zone from the oldest and westernmost caldera (Ucanca, $1.02 \mathrm{Ma}$ ) to the youngest and easternmost caldera (Diego Hernández, $0.18 \mathrm{Ma})$.

The general coincidence between the SP + AMT (SP calibrated with AMT) and AMT-alone maps of the water table topography is reasonable, since we have used AMT data to transform SP into values of the thickness of the vadose zone and therefore both maps are not completely independent. Nevertheless, because SP data coverage is denser, it should allow to describe more subtle details, which will be better evidenced examining the differences between SP + AMT and AMT-alone models of the topography of Diego Hernández water table. The main differences are: a more valley-like, SW-NE elongated geometry of the SP anomaly comparing to audiomagnetotellurics; a slight displacement to the north of the SP minimum; and an evident extension of low SP values to the head of La Orotava Valley. Also, the elevation of the water table at the two wells predicted by the SP + AMT model (Table 1) are too low, with offsets of $-338 \mathrm{~m}$ at W-DH and $-149 \mathrm{~m}$ at W-Gj, although the model at least predicts correctly a greater elevation in $\mathrm{W}-\mathrm{Gj}$ (incidentally, the water table level at $\mathrm{W}$-DH has been observed to decrease with time almost linearly, with a rate of $\sim 2.4 \mathrm{~m} /$ year between 2000 and 2006 according to Farrujia et al., 2006; since the SP measurements were performed more than 5 years after the audiomagnetotelluric measurements, a difference between wells around $80 \mathrm{~m}$ is reasonable for SP-measuring times, but the obtained value of $251 \mathrm{~m}$ is too high). These mismatches must be due to the fact that big-scale interpolation maps of discrete data points are being used and also because SP values depend on more variables apart from the thickness of the vadose zone: they are also influenced both by lateral fluxes over or inside the water table (which in reality is not a perfect conductor), and also by the detailed resistivity structure of the materials between the terrain surface and the water table, which can deform the geometry of the equipotential surfaces. Nevertheless, these results reaffirm the previous conclusions about the different hydrogeological behaviors of the three calderas and about the funnel-shape anomaly detected for Diego Hernández caldera. In addition, they highlight the connection between Diego Hernández and La Orotava Valley groundwater systems, which allows an apparent groundwater flux from Diego Hernández to the head of La Orotava Valley.

\subsection{Previous SP works}

Some remarks can be made about how the results of the present SP study relate with previous SP works. Although the general results outlined by Aubert and Kieffer $(1996,1998)$ are confirmed, in particular regarding the independent behavior of the three calderas and the existence of negative anomalies around Montaña Blanca, the much bigger data set and wider coverage of the present study has allowed a much more complete mapping of the anomalies and a robust interpretation. The semicircular negative anomaly around M. Blanca reported by Aubert and Kieffer (1996) is now revealed as a circular set of SP lows surrounding a relative SP maximum that defines the extension of a hydrothermal system associated to M. Blanca edifice. Both Aubert and Kieffer (1996) and Ohno et al. (2004), based just on one SP profile running from Teide summit to the caldera floor through M. Blanca, detected the existence of a SP maximum amounting to $\sim 600 \mathrm{mV}$ centered in Teide edifice and correctly related it to the hydrothermal system of Teide volcano. The SP mapping presented here has confirmed this maximum and has measured it along 4 profiles radiating from Teide summit to the four cardinal directions, allowing a much more complete mapping of the surface extension of Teide hydrothermal system and its subdivision in three zones (summit crater, upper and lower hydrothermal systems).

SP measurements along a SW-NE profile across Diego Hernández caldera lead Aubert and Kieffer (1998) to suggest that the water table within this caldera, and hence the topography of the caldera floor, was deepening to the NE, interpreting it as the result of a lateral landslide origin of Diego Hernández to the NE. The complete SP mapping of Diego Hernández reveals, by contrast, a funnel shaped negative anomaly elongated to the NE, indicating that although the hydrogeological system of Diego Hernández is partially open to La Orotava Valley, it corresponds to an enclosed system coherent with a vertical collapse origin of this caldera.

\subsection{SP and the recent magma feeding system of Tenerife}

A final comment about the hydrothermal systems detected by the SP mapping in central Tenerife and their relation to young volcanic edifices and recent volcanic activity seems pertinent. Not surprisingly, the strongest and widest systems are those of Teide and Pico Viejo. Since their total (maximum-to-minimum) SP signatures are similar (600$700 \mathrm{mV}$ ), it is reasonable to infer a similar level of fluid convection activity in both systems, although an obvious difference between them is the presence of fumarolic fields in Teide upper cone and their apparent absence in Pico Viejo. Another difference is the presence of high soil $\mathrm{CO}_{2}$ concentrations and fluxes in Teide upper cone and their apparent absence in Pico Viejo (Hernández et al., 2000; Galindo, 2005); although the published $\mathrm{CO}_{2}$ data coverage of Pico Viejo (Hernández et al., 2000) is too poor to obtain definitive conclusions, a future confirmation of the absence of $\mathrm{CO}_{2}$ anomalies over Pico Viejo would need explanation. These differences between the surface manifestations of Teide and Pico Viejo hydrothermal systems could be due either to the much more localized extension of Teide summit hydrothermal system, which probably indicates a more efficient channelization of hot ascending fluids by structural boundaries towards the summit, or to differences in the level of compaction and porosity of the upper materials of both edifices, which could allow different degrees of subsurface air circulation and ventilation, with corresponding differences in the underground condensation level of hot ascending gasses. Self-sealing hydrothermal processes, which could prevent diffuse $\mathrm{CO} 2$ venting to the surface due to the presence of very low permeability materials, should also be considered as a potential explicative factor for these differences.

Two additional hydrothermal systems have been detected in M. Blanca and M. Rajada phonolitic satellite edifices, and the summit crater hydrothermal system of Pico Viejo seems to extend towards the vent of M. Chahorra phono-tephritic historical eruption (1798 AD). Although no SP positive hydrothermal anomaly has been detected over other important phonolitic flank vents like Roques Blancos or Pico Cabras at the northern slopes of Pico Viejo and Teide, respectively, our data coverage is clearly insufficient to discard the actual existence of localized hydrothermal systems at these edifices. On the other hand, some SP profiles have been measured in the area of two historical mafic eruptions: Siete Fuentes and Chinyero in the NE and NW rift zones, respectively (Fig. 3). At both places slight decreases in the SP signal have been detected, although they are not so evident in the interpolated SP maps. These slight decreases are most probably caused by preferential meteoric water infiltration through the fracture systems feeding these eruptions and/or through the highly porous, scoriaceous material of their surficial cones. Similarly, no general hydrothermal activity is detected at the NE and NW rift zones, which is coherent with the absence of significant $\mathrm{CO}_{2}$ flux anomalies over both rift systems when the volcanic system is at rest (Galindo, 2005). Positive SP values are indeed detected in the outer parts of the NW rift zone, but they are readily explained by a combination of the topographic effect and the presence of a shallower water-table laterally confined by the dense web of mafic dykes reaching the surface at the rift, without need to invoke any hydrothermal activity. This absence of continuous hydrothermal activity from the summit of the rift zones is in contrast with what is known from other volcanic islands like Hawaii (Zablocki, 1976) or La Reunion island (Barde-Cabusson et al., 2012), where either shallow mafic magma reservoirs below rift systems or high magma 
extrusion rates and correspondingly long-lived thermal anomalies sustain active hydrothermal convection that is detected by continuous positive SP anomalies running from the summit towards the rift zone axis.

All the previous characteristics are coherent with what is known about Tenerife recent magma feeding system. This system is responsible of a strong bimodality of recently extruded materials, with mafic materials erupted through monogenetic vents along both the NE and the NW rift zones and intermediate to felsic materials erupted both through Teide-Pico Viejo central conduits and through their flank satellite vents (Ablay and Martí, 2000; Wiesmaier et al., 2012). Petrologic studies have determined that intermediate to felsic materials erupted through Teide and Pico Viejo central conduits come from central magma chambers located at a depth of $\sim 4-5 \mathrm{~km}$ below the present summits (Ablay et al., 1998; Andújar et al., 2010). Materials erupted through intermediate to felsic flank vents have been reported to originate at much shallower magma reservoirs at 1-2 km depth (Andújar et al., 2013). By contrast, mafic materials erupted through the rift zones are fed by dykes directly from the uppermost mantle or the mantle-crust transition, with minor accumulation at shallower levels. This is in agreement with magma behavior during the recent submarine basanitic eruption occurred in 2011-2012 at the southern rift zone of El Hierro island (López et al., 2012; Meletlidis et al., 2012; Sigmarsson et al., 2012; Martí et al., 2013), which could be used as an analogue for similar mafic eruptions in other Canary islands.

It seems that sustained hydrothermal activity, as evidenced by SP measurements, is present in the volcanic edifices that overlain felsic magma chambers at 4-5 km depth (Teide and Pico Viejo) and at least also over some of the satellite felsic reservoirs at 1-2 km depth (M. Blanca, M. Rajada), while it is absent from the mafic rift systems and monogenetic cones, even when at least two of these cones have erupted as recently as 1909 AD (Chinyero) and 1704-1705 AD (Siete Fuentes). Long-lived, volumetrically important shallow magma reservoirs are apparently the heat sources required to sustain strong hydrothermal circulation in the upper parts of the crust, a condition satisfied by felsic magma reservoirs but not matched by mafic magma batches that seem to stall at the mantle-crust boundary before ascending directly from there to the surface by small dyke systems that cool quickly after the end of the corresponding eruptions and that are not able to sustain any hydrothermal system during periods longer than perhaps some tens of years.

\section{Conclusions}

The self-potential survey described in this paper has revealed the surface extension and structure of the hydrothermal system of central Tenerife. Strong hydrothermal activity has been detected in Teide and Pico Viejo edifices, while weaker hydrothermal systems, either active or fossil, are observed in Montaña Blanca and Montaña Rajada flank satellite felsic vents. SP data seem to indicate also the presence of fossil hydrothermal activity along some parts of the floor of Las Cañadas caldera walls. By contrast, no wide-scale hydrothermal activity is present in the proximal parts of the NE and NW rift zones, including the historical mafic eruptions of Chinyero (1909 AD) and Siete Fuentes (1704-1705 AD). This correlates well with what is known about the magmatic feeding system of Tenerife, with shallower reservoirs feeding the felsic eruptions and a deeper origin of mafic materials. According to their SP signal, hydrothermal systems of Teide and Pico Viejo can be subdivided in three different parts: an uppermost part confined to the summit craters, and extending to the west of Pico Viejo crater towards the vents of Montaña Chahorra historical eruption (1798 AD); an upper hydrothermal system in the upper flank of the edifices; and a lower hydrothermal system in the middle flanks. These subdivisions must be connected with the unknown internal structure of the edifices. The extension of these hydrothermal systems is wide and coincides well with gravimetric low density anomalies, indicating that a very significant fraction of the volume of Teide and Pico Viejo stratovolcanoes must be affected by hydrothermal rock alteration processes, although the degree to which such alteration has proceeded is unknown. This has potentially important implications for any assessment of the mechanical conditions of the interior of these volcanic edifices.

A funnel-shaped negative SP anomaly has been mapped in Diego Hernández caldera. It is most probably related with the underground topography of the caldera floor. With the help of previously published audiomagnetotelluric results, SP data have been converted to a model of the topography of the water table in Diego Hernández, which clearly constitutes a groundwater system partially open to La Orotava Valley and independent of Guajara and Ucanca calderas. The groundwater systems of these other two calderas seem to be also independent and enclosed, although probably connected between them. The SP signal in the Icod Valley is clearly compatible with a flank collapse origin, although the present SP data by themselves are not able to locate the headwall of this collapse. These results seem to favor the view of Las Cañadas caldera as being originated by a combination of both vertical and lateral collapses.

Finally, a quasi-linear negative SP anomaly is observed to the west of Pico Viejo and aligned with the NW rift zone direction, suggesting preferential meteoric water infiltration along the dykes and fractures affecting this zone.

One possible future development of this work could be to use electrical resistivity tomography (ERT), as well as other geophysical techniques like controlled source audiomagnetotellurics (CSAMT), to image with high resolution the deep structure of the detected hydrothermal systems (up to $600 \mathrm{~m}$ applying ERT with $2.5 \mathrm{~km}$-long cable and $40 \mathrm{~m}$-spacing between electrodes).

\section{Acknowledgments}

We are grateful to the Cabildo de Tenerife and the Parque Nacional del Teide for their authorization to work in this Unesco World Heritage Site. We thank the Teleférico del Teide for the support and facilities during fieldwork in the upper part of Teide and Pico Viejo edifices. We are grateful to the Parador Nacional de las Cañadas del Teide, the Observatorio Astronómico del Teide and the Observatorio Meteorológico de Izaña for their facilities and help. Thanks to Clelia and Cristina Perez from www.casateide.es for their lodging and warmth. We express our most sincere gratitude and friendship to Francisco Orta of the Guard Staff of the Parque Nacional del Teide, whose logistical support was the keystone to success in the most difficult part of the fieldwork, the north faces of Teide and Pico Viejo. We are grateful to A. Revil and J. F. Lénat for their constructive reviews. This work has been funded by the Instituto Geográfico Nacional (Ministerio de Fomento, Gobierno de España). S. Barde-Cabusson was funded by JAE-Doc Program (JAEDoc 09 01319).

\section{References}

Abdel-Monem, A., Watkins, N.D., 1972. Potassium-argon ages, volcanic stratigraphy and geomagnetic polarity history of the Canary Islands: Tenerife, La Plama and Hierro. Am. J. Sci. 272, 805-825.

Ablay, G., Hürlimann, M., 2000. Evolution of the north flank of Tenerife by recurrent giant landslides. J. Volcanol. Geotherm. Res. 103, 135-159.

Ablay, G.J., Keary, P., 2000. Gravity constraints on the structure and volcanic evolution of Tenerife, Canary Islands. J. Geophys. Res. 105 (B3), 5783-5796.

Ablay, G.J., Martí, J., 2000. Stratigraphy, structure and volcanic evolution of the Pico Teide-Pico Viejo formation, Tenerife, Canary Islands. J. Volcanol. Geotherm. Res. 103, 175-208.

Ablay, G., Ernst, G.G.J., Martí, J., Sparks, R.S.J., 1995. The 2 ka subplinian eruption of Montaña Blanca, Tenerife. Bull. Volcanol. 57, 337-355.

Ablay, G.J., Carroll, M.R., Palmer, M.R., Martí, J., Sparks, R.S., 1998. Basanite-phonolite lineages of the Teide-Pico Viejo volcanic complex, Tenerife, Canary Islands. J. Petrol. 39, 905-936.

Aizawa, K., 2008. Classification of self-potential anomalies on volcanoes and possible interpretations for their subsurface structure. J. Volcanol. Geotherm. Res. 175, 253-268.

Aizawa, K., Yoshimura, R., Oshiman, N., Yamazaki, K., Uto, T., Ogawa, Y., Tank, S.B., Kanda, W., Sakanaka, S., Furukawa, Y., Hashimmoto, T., Uyeshima, M., Ogawa, T., Shiozaki, I., 
Hurst, A.W., 2005. Hydrothermal system beneath Mt. Fuji volcano inferred from magnetotellurics and electric self-potential. Earth Planet. Sci. Lett. 235, 343-355.

Aizawa, K., Ogawa, Y., Ishido, T., 2009. Groundwater flow and hydrothermal systems within volcanic edifices: delineation by electric self-potential and magnetotellurics. J. Geophys. Res. 114, B01208. http://dx.doi.org/10.1029/2008/B005910.

Almendros, J., Ibáñez, J.M., Carmona, E., Zandomeneghi, D., 2007. Array analyses of volcanic earthquakes and tremor recorded at Las Cañadas caldera (Tenerife Island, Spain) during the 2004 seismic activation of Teide volcano. J. Volcanol. Geotherm. Res. 160, 285-299.

Ancochea, E., Fúster, J.M., Ibarrola, E., Cendrero, A., Coello, J., Hernán, F., Cantagrel, J.M., Jamond, C., 1990. Volcanic evolution of the island of Tenerife (Canary Islands) in the light of new K-Ar data. J. Volcanol. Geotherm. Res. 44, 231-249.

Ancochea, E., Huertas, M.J., Cantagrel, J.M., Coello, J., Fúster, J.M., Arnaud, N., Ibarrola, E., 1999. Evolution of the Cañadas edifice and its implications for the origin of the Cañadas Caldera (Tenerife, Canary Islands). J. Volcanol. Geotherm. Res. 88, 177-199.

Andújar, J., Costa, F., Martí, J., 2010. Magma storage conditions of the last eruption of Teide volcano (Canary Islands, Spain). Bull. Volcanol. 72, 381-395.

Andújar, J., Costa, F., Scaillet, B., 2013. Storage conditions and eruptive dynamics of centra versus flank eruptions in volcanic islands: the case of Tenerife (Canary Islands, Spain). J. Volcanol. Geotherm. Res. 260, 62-79.

Antoine, R., Baratoux, D., Rabinowicz, M., Fontaine, F., Bachèlery, P., Staudacher, T., Saracco, G., Finizola, A., 2009. Thermal infrared image analysis of a quiescent cone on Piton de la Fournaise volcano: evidence of convective air flow within an unconsolidated soil. J. Volcanol. Geotherm. Res. 183, 228-244.

Araña, V., 1971. Litología y estructura del edificio Cañadas, Tenerife (Islas Canarias). Estud. Geol. 27, 95-135.

Araña, V., Camacho, A.G., García, A., Montesinos, F.G., Blanco, I., Vieira, R., Felpeto, A., 2000. Internal structure of Tenerife (Canary Islands) based on gravity, aeromagnetic and volcanological data. J. Volcanol. Geotherm. Res. 103, 43-64.

Aubert, M., Kieffer, G., 1996. Schéma d'évolution d'un dôme phonolitique à la base du Pic du Teide (Espagne), déduit de données géoélectriques et morphologiques. C. R. Acad. Sci. Paris, 323, série IIa 645-650.

Aubert, M., Kieffer, G., 1998. Hypothèse d'un processus de glissement sur le secteur nord-est de la caldera de Las Cañadas del Teide (Tenerife, Canaries, Espagne): arguments géophysiques et morpho-structuraux. C. R. Acad. Sci. Paris 326, 87-92.

Aubert, M., Dana, I.N., Gourgaud, A., 2000. Internal structure of the Merapi summit from self-potential measurements. J. Volcanol. Geotherm. Res. 100, 337-343.

Aubert, M., Diliberto, S., Finizola, A., Chébli, Y., 2008. Double origin of hydrothermal convective flux variations in the Fossa of Vulcano (Italy). Bull. Volcanol. 70, 743-751.

Barde-Cabusson, S., Merle, O., 2007. From steep-slope volcano to flat caldera floor. Geophys. Res. Lett. 34, L10305. http://dx.doi.org/10.1029/2007GL029784.

Barde-Cabusson, S., Finizola, A., Peltier, A., Chaput, M., Taquet, N., Dumont, S., Duputel, Z., Guy, A., Mathieu, L., Saumet, S., Sorbadère, F., Vieille, M., 2012. Structural control of collapse events inferred by self-potential mapping on the Piton de la Fournaise volcano (La Réunion Island). J. Volcanol. Geotherm. Res. 209-210, 9-18.

Bennati, L., Finizola, A., Walker, J.A., Lopez, D.L., Higuera-Diaz, I.C., Schütze, C., Barahona, F., Cartagena, R., Conde, V., Funes, R., Rios, C., 2011. Fluid circulation in a complex volcano-tectonic setting, inferred from self-potential and soil $\mathrm{CO}_{2}$ flux surveys: the Santa María-Cerro Quemado-Zunil volcanoes and Xela caldera (Northwestern Guatemala). J. Volcanol. Geotherm. Res. 199, 216-229.

Blanco-Montenegro, I., Nicolosi, I., Pignatelli, A., García, A., Chiapinni, M., 2011. New evidence about the structure and growth of ocean island volcanoes from aeromagnetic data: the case of Tenerife, Canary Islands. J. Geophys. Res. 116, B03102. http://dx.doi.org/10.1029/ 2010JB007646.

Bravo, T., 1962. El circo de Cañadas y sus dependencias. Bol. R. Soc. Esp. Hist. Nat. 40, 93-108.

Bryan, S.E., Martí, J., Cas, R.A.F., 1998. Stratigraphy of the Bandas del Sur Formation: an extracaldera record of Quaternary phonolitic explosive eruptions from the Las Cañadas edifice, Tenerife (Canary Islands). Geol. Mag. 135, 605-636.

Bryan, S.E., Cas, R.A.F., Martí, J., 2000. The 0.57 Ma plinian eruption of the Granadilla Member, Tenerife (Canary Islands): an example of complexity in eruption dynamics and evolution. J. Volcanol. Geotherm. Res. 103, 209-238.

Byrdina, S., Ramos, D., Vandemeulebrouck, J., Masias, P., Revil, A., Finizola, A. Gonzales-Zuñiga, K., Cruz, V., Antayhua, Y., Macedo, O., 2013. Influence of the regiona topography on the remote emplacement of hydrothermal systems with examples of Tiscani and Ubinas volcanoes, Sothern Peru. Earth Planet. Sci. Lett. 365, 152-164.

Camacho, A.G., Fernández, J., Gottsmann, J., 2011. The 3-D gravity inversion package GROWTH2.0 and its application to Tenerife Island, Spain. Comput. Geosci. 37, $621-633$

Canales, J.P., Dañobeitia, J.J., Watts, A., 2000. Wide-angle seismic constraints on the internal structure of Tenerife, Canary Islands. J. Volcanol. Geotherm. Res. 103, 65-81.

Carracedo, J.C., 1994. The Canary Islands: an example of structural control on the evolution of large ocean islands volcanoes. J. Volcanol. Geotherm. Res. 60, 225-241.

Carracedo, J.C., Rodríguez-Badiola, E., Guillou, H., Paterne, M., Scaillet, S., Pérez-Torrado, F.J., Paris, R., Fra-Paleo, U., Hansen, A., 2007. Eruptive and structural history of Teide Volcano and rift zones of Tenerife, Canary Islands. GSA Bulletin 119, 1027-1051.

Cecchi, E., Wyk, Van, de Vries, B., Lavest, J.M., 2005. Flank spreading and collapse of weak-cored volcanoes. Bull. Volcanol. 67, 72-91.

Coello, J., 1973. Las series volcánicas en subsuelos de Tenerife. Estud. Geol. 29, 491-512.

Coppo, N., Schnegg, P.A., Heise, W., Falco, P., Costa, R., 2008. Multiple caldera collapses inferred from the shallow electrical resistivity signature of the Las Cañadas caldera, Tenerife, Canary Islands. J. Volcanol. Geotherm. Res. 170, 153-166.

Coppo, N., Schnegg, P.A., Falco, P., Costa, R., 2009. A deep scar in the flank of Tenerife (Canary Islands): geophysical contribution to tsunami hazard assessment. Earth Planet. Sci. Lett. 282, 65-68.
Coppo, N., Schnegg, P.A., Costa, R., 2010. Conductive structures around Las Cañadas caldera, Tenerife (Canary Islands, Spain): a structural control. Geol. Acta 8, 67-82.

Corwin, R.F., 1997. The self-potential method for environmental and engineering applications: geotechnical and environmental geophysics. In: Ward, H. (Ed.), Investigations in Geophysics. Society of Exploration Geophysicists, 5, p. 1.

Corwin, R.F., Hoover, D.B., 1979. The self-potential method in geothermal exploration. Geophysics 44, 226-245.

Del Potro, R., Hürlimann, M. 2009. The decrease in the shear strength of volcanic materials with argillic hydrothermal alteration, insights from the summit region of Teide stratovolcano, Tenerife. Eng. Geol. 104, 135-143.

Del Potro, R., Pinkerton, H., Hürlimann, M., 2009. An analysis of the morphological, geological and structural features of Teide stratovolcano, Tenerife. J. Volcanol. Geotherm. Res. 181, 89-105.

Domínguez-Cerdeña, I., del Fresno, C., Rivera, L., 2011. New insight on the increasing seismicity during Tenerife's 2004 volcanic reactivation. J. Volcanol. Geotherm. Res. 206, 15-29.

Edgar, C.J., Wolff, J.A., Nichols, H.J., Cas, R.A.F., Martí, J., 2002. A complex Quaternary ignimbrite-forming phonolitic eruption: the Poris Member of the Diego Hernández Formation (Tenerife, Canary Islands). J. Volcanol. Geotherm. Res. 118, 99-130.

Edgar, C.J., Wolff, J.A., Olin, P.H., Nichols, H.J., Pittari, A., Cas, R.A.F., Reiners, P.W., Spell, T.L., Martí, J., 2007. The late Quaternary Diego Hernández Formation, Tenerife: volcanology of a complex cycle of voluminous explosive phonolitic eruptions. J. Volcanol. Geotherm. Res. 160, 59-85.

Farrujia, I., Braojos, J.J., Fernández, J., 2001. Ejecución de dos sondeos profundos en Las Cañadas del Teide. Comunicaciones VII Simposio de Hidrogeología, vol. XXIII. Asociación Española de Hidrogeólogos, Murcia, Spain (28 May-1 June, 2001, www. aguastenerife.org (2013)).

Farrujia, I., Velasco, J.L., Fernández, J., Martín, M.C., 2004. Evolución del nivel freático en la mitad oriental del acuífero de Las Cañadas del Teide. Cuantificación de parámetros hidrogeológicos. Comunicaciones VIII Simposio de Hidrogeología, vol. XXVII. Asociación Española de Hidrogeólogos, Zaragoza, Spain (18-22 October 2004. www.aguastenerife.org (2013)).

Farrujia, I., Braojos, J.J., Fernández, J.D., 2006. Evolución cuantitativa del sistema acuífero de Tenerife. Comunicaciones III Congreso de ingeniería civil, territorio y medio ambiente. Agua, Biodiversidad e Ingeniería, Zaragoza, Spain, pp. 25-27 (October 2006. www.aguastenerife.org (2013)).

Finizola, A., Sortino, F., Lénat, J.F., Valenza, M., 2002. Fluid circulation at Stromboli volcano (Aeolian Islands, Italy) from self-potential and $\mathrm{CO}_{2}$ surveys. J. Volcanol. Geotherm. Res. $116,1-18$

Finizola, A., Sortino, F., Lénat, J.F., Aubert, M., Ripepe, M., Valenza, M., 2003. The summit hydrothermal system of Stromboli. New insights from self-potential, temperature, $\mathrm{CO}_{2}$ and fumarolic fluid measurements, with structural and monitoring implications. Bull. Volcanol. 65, 486-504.

Finizola, A., Lénat, J.F., Macedo, O., Ramos, D., Thouret, J.C., Sortino, F., 2004. Fluid circulation and structural discontinuities inside Misti volcano (Peru) inferred from self-potential measurements. J. Volcanol. Geotherm. Res. 135, 343-360.

Finizola, A., Revil, A., Rizzo, E., Pisticelli, S., Ricci, T., Morin, J., Angeletti, B., Mocochain, L., Sortino, F., 2006. Hydrogeological insights at Stromboli volcano (Italy) from geoelectrical, temperature and $\mathrm{CO}_{2}$ soil degassing investigations. Geophys. Res. Lett. 33, L17304. http://dx.doi.org/10.1029/2006GL026842.

Finizola, A., Ricci, T., Deiana, R., Barde-Cabusson, S., Rossi, M., Praticelli, N., Giocoli, A., Romano, G., Delcher, E., Suski, B., Revil, A., Menny, P., Di Gangi, F., Letort, J., Peltier, A., Villasante-Marcos, V., Douillet, G., Avard, G., Lelli, M., 2010. Adventive hydrothermal circulation on Stromboli volcano (Aeolian Islands, Italy) revealed by geophysical and geochemical approaches: implications for general fluid flow models on volcanoes. J. Volcanol. Geotherm. Res. 196, 111-119.

Fox, R.W., 1830. On the electromagnetic properties of metalliferous veins in the mines of Cornwall. Philos. Trans. R. Soc. Lond. 120 (26-28), 399-414.

Galindo, I., 2005. Estructura volcano-tectónica y emisión difusa de gases de Tenerife (Islas Canarias). (Ph.D. Thesis) Universidad de Barcelona (350 pp.).

Galindo, I., Soriano, C., Martí, J., Pérez, N., 2005. Graben structure in the Las Cañadas edifice (Tenerife, Canary Islands): implications for active degassing and insights on the caldera formation. J. Volcanol. Geotherm. Res. 144, 73-87.

García de la Noceda, C., Sánchez Guzmán, J., Espejo, J., Fernández, M.C., García de la Noceda, C., Sánchez Guzmán, J., Espejo, J., Fernández, M.C., 1989. Termometría de infrarrojos en la Caldera de Las Cañadas. In: Araña, V., Coello, C. (Eds.), Los volcanes y la caldera del Parque Nacional del Teide (Tenerife, Islas Canarias). Publicaciones del Ministerio de Agricultura, Pesca y Alimentación, ICONA, Madrid, pp. 409-415.

García, A., Vila, J., Ortiz, R., Macià, R., Sleeman, R., Marrero, J.M., Sánchez, N., Tárraga, M., Correig, A.M., 2006. Monitoring the reawakening of Canary Islands' Teide volcano. EOS Trans. AGU. 87, 61-65.

Gaudin, D., Beauducel, F., Allemand, P., Delacourt, C., Finizola, A., 2013. Heat flux measurement from thermal infrared imagery in low-flux fumarolic zone: example of the Ty fault (La Soufrière de Guadeloupe). J. Volcanol. Geotherm. Res. 267, 47-56.

Giggenbach, W.F., 1996. In: Monitoring and Mitigation of Volcano Hazards (Ed.), Chemical composition of volcanic gases. Scarpa and Tilling, pp. 221-256.

Gottsmann, J., Wooller, L., Martí, J., Fernández, J., Camacho, A.G., González, P.J., García, A., Rymer, H., 2006. New evidence for the reawakening of Teide volcano. Geophys. Res. Lett. 33, L20311. http://dx.doi.org/10.1029/2006GL027523.

Gottsmann, J., Camacho, A.G., Martí, J., Wooller, L., Fernández, J., García, A., Rymer, H., 2008. Shallow structure beneath the Central Volcanic Complex of Tenerife from new gravity data: implications for its evolution and recent reactivation. Phys. Earth Planet. Inter. 168, 212-230.

Guillou, H., Carracedo, J.C., Paris, R., Pérez-Torrado, F.J., 2004. Implications for the early shield-stage evolution of Tenerife from $\mathrm{K} / \mathrm{Ar}$ ages and magnetic stratigraphy. Earth Planet. Sci. Lett. 222, 599-614. 
Hase, H., Hashimoto, T., Sakanaka, S., Kanda, W., Tanaka, Y., 2005. Hydrothermal system beneath Aso volcano as inferred from self-potential mapping and resistivity structure. J. Volcanol. Geotherm. Res. 143, 259-277.

Hernández, P., Pérez, N., Salazar, J., Sato, M., Notsu, K., Wakita, H., 2000. Soil gas CO2, CH4, and $\mathrm{H} 2$ distribution in and around Las Cañadas caldera, Tenerife, Canary Islands, Spain. J. Volcanol. Geotherm. Res. 103, 425-438.

Hürlimann, M., Turon, E., Martí, J., 1999. Large landslides triggered by caldera collapse events in Tenerife, Canary Islands. Phys. Chem. Earth (A) 24, 921-924.

Hürlimann, M., Marti, J., Ledesma, A., 2004. Morphological and geological aspects related to large slope failures on oceanic islands. The huge La Orotava landslides on Tenerife, Canary Islands. Geomorphology 62, 143-158.

Ingebritsen, S.E., Sabfird, W.E., Neuzil, C.E., 2006. Groundwater in Geologic Processes. Cambridge University Press, Cambridge, U.K.(564 pp.).

Ingebritsen, S.E., Geiger, S., Hurwitz, S., Driesner, T., 2010. Numerical simulation of magmatic hydrothermal systems. Rev. Geophys. 48 (RG1002/2010, 8755-1209/10/ 2009RG000287)

Ishido, T., 2004. Electrokinetic mechanism for the "W"-shaped self-potential profile on volcanoes. Geophys. Res. Lett. 31, L15616. http://dx.doi.org/10.1029/2004GL020409.

Ishido, T., Mizutani, H., 1981. Experimental and theoretical basis of electrokinetic phenomena in rock-water systems and its applications to geophysics. J. Geophys. Res. 86 (B3), 1763-1775.

Ishido, T., Pritchett, J.W., 1999. Numerical simulation of electrokinetic potentials associated with subsurface fluid flow. J. Geophys. Res. 104 (B7), 15247-15259.

Kanda, W., Mori, S., 2002. Self-potential anomaly of Satsuma-Iwojima volcano. Earth Planets Sapce 54, 231-237.

Kerle, N., Wyk, Van, de Vries, B., 2001. The 1998 debris avalanche at Casita volcano. Nicaragua. Investigation of structural deformation as the cause of slope instability using remote sensing. J. Volcanol. Geotherm. Res. 105, 49-63.

Le Friant, A., Boudon, G., Deplus, C., Villemant, B., 2003. Large-scale flank collapse events during the activity of Montagne Pelée, Martinique, Lesser Antilles. J. Geophys. Res. 108 (B1), 2055. http://dx.doi.org/10.1029/2001JB001624.

Le Friant, A., Harford, C.L., Deplus, C., Boudon, G., Sparks, R.S.J., Herd, R.A., Komorowski, J.C., 2004. Geomorphological evolution of Montserrat (West Indies): importance of flank collapse and erosional processes. J. Geol. Soc. Lond. 161, 147-160.

Lopez, D.L., Williams, S.N., 1993. Catastrophic volcanic collapse: relation to hydrothermal processes. Science 260, 1794-1796.

López, C., Blanco, M.J., Abella, R., Brenes, B., Cabrera-Rodríguez, V.M., Casas, B., Domínguez-Cerdeña, I., Felpeto, A., Fernández de Villalta, M., del Fresno, C., García-Arias, M.J., García-Cañada, L., Gomis-Moreno, A., González-Alonso, E., Guzmán-Pérez, J., Iribarren, I., López-Díaz, R., Luengo-Oroz, N., Meletlidis, S. Moreno, M., Moure, D., Pereda de Pablo, J., Rodero, C., Romero, E., Sainz-Maza, S., Sentre-Domingo, M.A., Torres, P.A., Trigo, P., Villasante-Marcos, V., 2012. Monitoring the volcanic unrest of El Hierro (Canary Islands) before the onset of the 2011-2012 submarine eruption. Geophys. Res. Lett. 39, LI3303. http:// dx.doi.org/10.1029/2012GL051846.

Márquez, A., López, I., Herrera, R., Martín-González, F., Izquierdo, T., Carreño, F., 2008 Spreading and potential instability of Teide volcano, Tenerife, Canary Islands. Geophys. Res. Lett. 35, L05305. http://dx.doi.org/10.1029/2007GL032625.

Marrero, R., López, D.L., Hernández, P.A., Pérez, N.M., 2008. Carbon dioxide discharged through the Las Cañadas Aquifer, Tenerife, Canary Islands. Pure Appl. Geophys. http://dx.doi.org/10.1007/s00024-007-0287-3.

Martí, J., Gudmundsson, A., 2000. The Las Cañadas caldera (Tenerife, Canary Islands): an overlapping collapse caldera generated by magma-chamber migration. J. Volcanol. Geotherm. Res. 103, 161-173.

Martí, J., Mitjavila, J., Araña, V., 1994. Stratigraphy, structure and geochronology of the Las Cañadas Caldera (Tenerife, Canary Islands). Geol. Mag. 131, 715-727.

Martí, J., Hürlimann, M., Ablay, G.J., Gudmundsson, A., 1997. Vertical and lateral collapses on Tenerife (Canary Islands) and other volcanic ocean islands. Geology 25, 879-882.

Martí, J., Geyer, A., Andujar, J., Teixidó, F., Costa, F., 2008. Assessing the potencial for future explosive activity from Teide-Pico Viejo stratovolcanoes (Tenerife, Canary Islands). J. Volcanol. Geotherm. Res. 178, 529-542.

Martí, J., Ortiz, R., Gottsmann, J., García, A., De la Cruz-Reyna, S., 2009. Characterising unrest during the reawakening of the central volcanic complex on Tenerife, Canary Islands, 2004-2005, and its implications for assessing hazards and risk mitigation. J. Volcanol. Geotherm. Res. 182, 23-33.

Martí, J., Castro, A., Rodríguez, C., Costa, F., Carrasquilla, S., Pedreira, R., Bolos, X., 2013. Correlation of magma evolution and geophysical monitoring during the 2011-2012 El Hierro (Canary Islands) submarine eruption. J. Petrol. 54, 1349-1373.

Masson, D., Watts, A., Gee, M., Urgeles, R., Mitchell, N., Bas, T.L., Canals, M., 2002. Slope failures on the flanks of the western Canary Islands. Earth Science Reviews 57, 1-35.

Matsushima, N., Michiwaki, M., Okazak, iN, Ichikawa, R., Takagi, A., Nishida, Y., 1990. Selfpotential studies in volcanic areas (2)- Usu, Hokkaido Komaga-take and Me-akan. J. Fac. Sci. Hokkaido Univ., Ser VII (Geophys.) 85, 465-477.

Meletlidis, S., Di Roberto, A., Pompilio, M., Bertagnini, A., Iribarre, I., Felpeto, A., Torres, P.A., D'Oriano, C., 2012. Xenopumices from the 2011-2012 submarine eruption of El Hierro (Canary Islands, Spain): constraints on the plumbing system and magma ascent. Geophys. Res. Lett. 39, L17302. http://dx.doi.org/10.1029/2012GL052675.

Merle, O., Lénat, J.F., 2003. Hybrid collapse mechanism at Piton de la Fournaise volcano, Reunion Island. Indian Ocean. J. Geophys. Res. 108 (B3), 2166.

Merle, O., Barde-Cabusson, S., Maury, R.C., Legendre, C., Guille, G., Blais, S., 2006. Volcano core collapse triggered by regional faulting. J. Volcanol. Geotherm. Res. 158, 269-280.

Michel, S., Zlotnicki, J., 1998. Self-potential and magnetic surveying of La Fournaise volcano (Reunion Island): correlations with faulting, fluid circulation and eruption. J. Geophys. Res. 103 (B8), 17845-17857.

Navarro, J.M., Coello, J., 1989. Depressions originated by landslide processes in Tenerife. ESF Meeting on Canarian Volcanism. 150-152.
Nishida, Y., Tomiya, H., 1987. Self-potential studies in volcanic areas (1)- Usu volcano. J.Fac. Sci. Hokkaido Univ. Ser VII (Geophys.) 8 (2), 173-190.

Nishida, Y., Matsushima, N., Goto, A., Nakayama, Y., Oyamada, A., Utsugi, M., Oshima, H. 1996. Self-potential studies in volcanic areas (3)- Miyake-jima, Esan and Usu. J. Fac. Sci. Hokkaido Univ. Ser VII (Geophys.) 10 (1), 63-77.

Ohno, M., Hashimoto, T., González, P., Padrón, E., Hernández, P.A., Pérez, N., 2004. Electric self-potential around Teide Volcano, Canary Islands. Abstracts of the International Symposium "Reducing volcanic risk in islands", June 2-6, 2004 (Tenerife (Spain)).

Peltier, A., Finizola, A., Douillet, G., Brothelande, E., Garaebiti, E., 2012. Structure of an active volcano associated with a resurgent block inferred from thermal mapping: the Yasur-Yenkahe volcanic complex (Vanuatu). J. Volcanol. Geotherm. Res. 243-244, 59-68.

Pérez, N., Hernández, P.A., Melián, G., Galindo, I., Padrón, E., Nolasco, D., Salazar, P., Pérez, V., Marrero, R., Coello, C., Barrancos, J., González, J., 2005. Premonitory geochemical and geophysical signatures of volcanic unrest at Tenerife, Canary Islands. European Geophysical Union. Geophys. Res. Abstr. 7 (EGU05-A-09993).

Pirajno, F., 2009. Hydrothermal Processes and Mineral Systems. Springer Science+Bussiness Media B.V., Dordrecht, Netherlands (1250 pp.).

Plan Hidrológico Insular de Tenerife, 2013. Cabildo de Tenerife. www.aguastenerife.org.

Pous, J., Heise, W., Schnegg, P.A., Muñoz, G., Martí, J., Soriano, C., 2002. Magnetotelluric study of the Las Cañadas caldera (Tenerife, Canary Islands): structural and hydrogeological implications. Earth Planet. Sci. Lett. 204, 249-263.

Quidelleur, X., Gillot, P.Y., Soler, V., Lefevre, J.C., 2001. K/Ar dating extended into the last millennium: application to the youngest e usive episode of theTeide volcano (Spain). Geophysical Research Letters 28, 3067-3070.

Reid, M.E., Sisson, T.W., Brien, D.L., 2001. Volcano collapse promoted by hydrotherma alteration and edifice shape, Mount Rainier, Washington. Geology 29, 779-782.

Revil, A., 2002. Comment on "Rapid fluid disruption: a source for self-potential anomalies on volcanoes" by M.J.S. Johnston, J.D. Byerlee and D. Lockner. J. Geophys. Res. 107 (B8). http://dx.doi.org/10.1029/2001JB000788.

Revil, A., Jardani, A., 2013. The self-potential method. Theory and Applications in Environmental Geosciences.Cambridge University Press, Cambridge, U.K.(369 pp.).

Revil, A., Pezard, P.A., 1998. Streaming electrical potential anomaly along faults in geothermal areas. Geophys. Res. Lett. 25, 3197-3200.

Revil, A., Pezard, P.A., Glover, P.W.J., 1999a. Streaming potential in porous media 1. Theory of the zeta potential. J. Geophys. Res. 104, 20021-20031.

Revil, A., Schwaeger, H., Cathles III, L.M., Manhardt, P.D., 1999b. Streaming potential in porous media 2 . Theory and application to geothermal systems. J. Geophys. Res. 104, 20033-20048.

Revil, A., Finizola, A., Sortino, F., Ripepe, M., 2004. Geophysical investigations at Strombol volcano, Italy: implications for ground water flow and paroxysmal activity. Geophys. J. Int. 157, 426-440.

Revil, A., Finizola, A., Piscitelli, S., Rizzo, E., Ricci, T., Crespy, A., Angeletti, B., Balaasco, M. Barde-Cabusson, S., Bennati, L., Boleve, A., Byrdina, S., Carzaniga, N., Di Gangi, F., Morin, J., Perrone, A., Rossi, M., Roulleau, E., Suski, B., 2008. Inner structure of La Fossa di Vulcano (Vulcano Island, southern Tyrrhenian Sea, Italy) revealed by high-resolution electric resistivity tomography coupled with self-potential, temperature and $\mathrm{CO}_{2}$ diffuse degassing measurements. J. Geophys. Res. 113, B07207. http:// dx.doi.org/10.1029/2007JB005394.

Revil, A., Johnson, T.C., Finizola, A., 2010. Three-dimensional resistivity tomography of Vulcan's forge, Vulcano Island, southern Italy. Geophys. Res. Lett. 37, L15308. http:// dx.doi.org/10.1029/2010GL043983.

Richards, K., Revil, A., Jardani, A., Henderson, F., Batzle, M., Haas, A., 2010. Pattern of shallow ground water flow at Mount Princeton Hot Springs, Colorado, using geoelectrical methods. J. Volcanol. Geotherm. Res. 198, 217-232.

Ridley, W.I., 1971. The origin of some collapse structures in the Canary Islands. Geol. Mag. $108,477-484$

Romagnoli, C., Casalbore, D., Chiocci, F.L., Bosman, A., 2009a. Offshore evidence of large-scale lateral collapses on the eastern flank of Stromboli, Italy, due to structurally-controlled, bilateral flank instability. Mar. Geol. 262, 1-13.

Romagnoli, C., Kokelaar, P.K., Casalbore, D., Chiocci, F.L., 2009b. Lateral collapses and active sedimentary processes on the northwestern flank of Stromboli volcano. Mar. Geol. 265, 101-119.

Siebert, L., Glicken, H., Ui, T., 1987. Volcanic hazards from Bezymianny- and Bandai-type eruptions. Bull. Volcanol. 49, 435-459.

Sigmarsson, O., Laporte, D., Carpentier, M., Devouard, B., Devidal, J.L., Marti, J., 2012. Formation of U-depleted rhyolite from a basanite at El Hierro. Contrib. Mineral. Petrol. 165, 601-622.

Sill, W.R., 1983. Self-potential from primary flows. Geophysics 48, 76-86.

Soler, V., Castro-Almazán, J.A., Viñas, R.T., Eff-Darwich, A., Sánchez-Moral, S., Hillaire-Marcel, C., Farrujia, I., Coello, J., De la Nuez, J., Martín, M.C., Quesada, M.L., Santana, E., 2004. High CO2 levels in boreholes at Teide volcano complex (Tenerife, Canary Islands): implications for volcanic activity monitoring. Pure Appl. Geophys. 161, 1519-1532.

Teide Group, 1997. Morphometric interpretation of the northwest and southwest slopes of Tenerife, Canary Islands. J. Geophys. Res. 102 (B9), 325-342.

Thirwall, M.F., Singer, B.S., Marriner, G.F., 2000. ${ }^{39} \mathrm{Ar}-{ }^{40} \mathrm{Ar}$ ages and geochemistry of the basaltic shield stage of Tenerife, Canary Islands, Spain. J. Volcanol. Geotherm. Res. 103, 247-297.

Tort, A., Finizola, A., 2005. Structural survey of Misti volcanic cone (southern Peru) combining elliptical Fourier function analysis of the volcano morphology and self-potential measurements. J. Volcanol. Geotherm. Res. 141, 283-297.

Triebold, S., Kronz, A., Wörner, G., 2006. Anorthite calibrated backscattered electron profiles, trace elements and growth textures in feldspars from the Teide-Pico Viejo volcanic complex (Tenerife). J. Volcanol. Geotherm. Res. $154,117-130$. 
Ulusoy, I., Labazuy, P., Aydar, E., Ersoy, O., Çubukçu, E., 2008. Structure of the Nemrut caldera (Eastern Anatolia, Turkey) and associated hydrothermal fluid circulation. J. Volcanol. Geotherm. Res. 174, 269-283.

Watts, A.B.., Masson, D.G., 1995. A giant landslide on the north flank of Tenerife, Canary Islands. J. Geophys. Res. 100, 487-494.

Wiesmaier, S., Troll, V.R., Carracedo, J.C., Ellam, R.M., Bindeman, I., Wolff, J.A., 2012 Bimodality of lavas in the Teide-Pico Viejo succession in Tenerife-the role of crustal melting in the origin of recent phonolites. J. Petrol. 53, 2465-2495.

Wyk, Van, de Vries, B., Francis, P.W., 1997. Catastrophic collapse at stratovolcanoes induced by gradual volcano spreading. Nature 387, 387-390.

Wyk, Van, de Vries, B., Self, S., Francis, P.W., Keszthelyi, L., 2001. A gravitational spreading origin for the Socompa debris avalanche. J. Volcanol. Geotherm. Res. 105, 225-247.
Zablocki, C.J., 1976. Mapping thermal anomalies on an active volcano by the self-potential method, Kilauea, Hawaii. Proceedings, 2nd U.N. Symposium of the development and use of geothermal resources, San Francisco, California, May 1975, 2, pp. 1299-1309.

Zlotnicki, J., Nishida, Y., 2003. Review on morphological insights of self-potential anomalies on volcanoes. Surv. Geophys. 24, 291-338.

Zlotnicki, J., Boudon, G., Viode, J.P., Delareu, J.F., Mille, A., Bruere, F., 1998. Hydrothermal circulation beneath Mount Pelée inferred by self-potential surveying. Structural and tectonic implications. J. Volcanol. Geoth. Res. 84, 73-91.

Zlotnicki, J., Sasai, Y., Toutain, J.P., Villacorte, E.U., Bernard, A., Sabit, J.P., Gordon Jr., J.M., Corpuz, E.G., Harada, M., Punongbayan, J.T., Hase, H., Nagao, T., 2008. Combined electromagnetic, geochemical and thermal surveys of Taal volcano (Philippines) during the period 2005-2006. Bull. Volcanol.. http://dx.doi.org/10.1007/s00445-008-0205-2. 